OPEN ACCESS

Edited by:

Sheona Elizabeth Shackleton, University of Cape Town, South Africa

Reviewed by:

Roberto Porro,

Brazilian Agricultural Research Corporation (EMBRAPA), Brazil Natasha Stacey

Charles Darwin University, Australia

*Correspondence: Laura K. Snook

I.snook@cgiar.org

Specialty section: This article was submitted to

People and Forests,

a section of the journa Frontiers in Forests and Global

Change

Received: 07 February 2020 Accepted: 20 May 2020

Published: 26 June 2020

Citation:

Maukonen P, Donn P and Snook LK (2020) Addressing Potential Conflict Using Participatory Mapping: Collection of Forest Foods From Timber Trees Around Industrial Concessions in Cameroon. Front. For. Glob. Change 3:72. doi: 10.3389/ffgc.2020.00072

\section{Addressing Potential Conflict Using Participatory Mapping: Collection of Forest Foods From Timber Trees Around Industrial Concessions in Cameroon}

\author{
Paulus Maukonen ${ }^{1}$, Pauline Donn ${ }^{1}$ and Laura K. Snook ${ }^{2 *}$ \\ ${ }^{1}$ Forest Genetic Resources Programme, Bioversity International, Yaounde, Cameroon, ${ }^{2}$ Forest Genetic Resources \\ Programme, Bioversity International, Rome, Italy
}

Extensive areas of Africa's humid tropical lowland forests have been allocated to timber concessions, but are also inhabited by villagers who obtain resources from the forest. Approximately $61 \%$ of timber species in the Congo Basin also yield locally used non-timber forest products (NTFP). Among these are fruits and oil from Moabi (Baillonella toxisperma), and edible caterpillars from Sapelli (Entandrophragma cylindricum), and Tali (Erythrophleum suaveolens). Participatory mapping was used to understand whether logging affects the availability of these food resources to men and women in villages near timber concessions in two areas of Cameroon. Mapping of collection trees and interviews of 20 male and 20 female collectors, in four villages near two logging concessions, showed that during 1-day collecting trips people walk an average of $2.7 \mathrm{~km}( \pm 1.42)$ to trees where they collect these resources. Food resources are typically collected by both men and women, but men travel further to specific trees, sometimes combining this with hunting excursions further into the forest. Only $14 \%$ of the collection trees were located within the logging concessions. However, $72 \%$ of Sapelli, $81 \%$ of Moabi, and $100 \%$ of Tali trees from which food resources were collected were larger than their legal felling diameters, meaning that logging could jeopardize the supply of foods from these species. Prioritizing food values over timber values of trees within a certain radius of villages, and excluding them from logging, would safeguard villagers' access to these food resources. Already, negotiations between villagers and concessionaires have been successful. Many of the mapped collection trees occurred in agroforestry areas delineated by the concessionaire for the use of villagers; another concessionaire had suspended felling of Moabi trees in response to requests by the villagers. However, an extensive and expanding local logging sector on community forests and other lands outside of industrial timber concessions means that conflicts are arising even within villages or settlements, between individuals who seek to obtain either a one-time financial windfall from felling a tree (usually a male interest); or ensure ongoing periodic harvests of foods (typically a priority of women, but also of local Baka pygmies).

Keywords: non-timber forest products (NTFP), Moabi, sapelli, tali, Baillonella toxisperma, Entandrophragma cylindricum, Erythrophleum suaveolens, edible caterpillars 


\section{INTRODUCTION}

The simultaneous demand for forest resources by rural people and timber concessionaires has been reported to represent a conflict of interest in tropical forests in Africa, as well as other tropical regions (Laird, 1999; Clark and Sunderland, 2004; Ndoye and Tieguhong, 2004; Vantomme et al., 2004; Hoare, 2007; Guariguata et al., 2010; Ingram and Schure, 2010; Rist et al., 2012). Timber concessions can reduce the availability of non-timber forest products (NTFPs) through three mechanisms: restriction of access to forest resources, logging of timber species that are also important sources of NTFPs, and indirect impacts of logging on other forest resources (Newing, 2007). Multiple resource management that integrates practices to sustain both timber and non-timber resources for multiple users, considering the needs of both women and men, could minimize such conflicts and increase the benefits obtained from tropical forests. However, it has been noted that few quantitative studies have been carried out to evaluate the impact of logging on the ability of local populations to obtain NTFPs (Rist et al., 2012). This study contributes to addressing this gap by determining which individual trees are sources of food resources collected by local people, in order to evaluate whether and to what degree men and women living in villages near timber concessions obtained food products from trees in concessions, which might be threatened by logging. The results can be used to contribute to reducing this potential conflict by providing a foundation for developing management practices to sustain both timber and non-timber resources for multiple users, in Cameroon and elsewhere in the Congo Basin as well as other tropical regions.

The population of Cameroon is estimated at 20 million, of whom $46 \%$ live in rural areas, many within or near forests (Tieguhong et al., 2012; The World Bank, 2016). This study was carried out in the South and East regions of Cameroon, where the majority of the country's 18.6 million ha of lowland dense humid forests occur (Bayol et al., 2012). These areas have a combined population of $\sim 1.5$ million people, $60 \%$ of whom live in rural areas (BUCREP, 2012). Non-timber forest products (NTFP) such as fruits, seeds, insects, bush meat, and traditional medicines, provide nutritional, and livelihood benefits to these communities (Laird, 1995; Ndoye et al., 1997; Ndoye and Tieguhong, 2004; Sunderland et al., 2004; Tieguhong and Ndoye, 2007; Tieguhong and Nkamgnia, 2012). Studies have revealed that some rural people in Cameroon obtain 50\% or more of their household income (cash and subsistence) from forest products (Van Djik, 1999; Sunderland et al., 2004), although a more recent study estimated this ratio as $<30 \%$, as compared to $\sim 50 \%$ obtained from farming (Levang et al., 2015). Many of these wild-gathered forest species are nutritionally important complements to their agricultural staples (Fungo et al., 2016, 2020; Noutcheu et al., 2016).

As of 2016, Cameroon had granted 91 timber concessions covering over 6.3 million ha (Cerutti et al., 2016) of the nation's 18.8 million ha of forest (FAO, 2016). Between 2006 and 2015 average annual production was $\sim 2.3$ million cubic meters (Cerutti et al., 2016). In 2012, when timber concessions occupied 5.8 million ha and produced nearly two million cubic meters of logs annually for European and Asian markets, they accounted for $\sim 6 \%$ of Cameroon's gross domestic product (GDP) (Bayol et al., 2012). In addition to this, more than 860,000 cubic meters of timber are consumed annually through informal domestic markets in major cities (Lescuyer et al., 2012). More than 80 tree species are felled for timber (MINFOF, 2005). An estimated $61 \%$ of these commercial timber species also produce NTFPs commonly collected and used by forest-dwelling people (Ndoye and Tieguhong, 2004; Tieguhong and Ndoye, 2007). In the Amazon, species with both timber and non-timber values have been referred to as "conflict-of-use" species (Shanley et al., 2012).

Since 1994 the management of concession forests in Cameroon has been governed by Forest Law No. 94-01, which mandates that logging companies prepare detailed forest management plans (FMPs) to ensure the ecological, economic, and socially sustainable management of their forests (Cerutti et al., 2008). Article 8 of the law recognizes the rights of local people to exploit NTFPs within the concessions for their personal use (although not in large quantities or for sale), as long as they are not protected species (Republic of Cameroon, 1994). However, there is very little information about local people's uses of forest resources and whether these conflict with current management of timber concessions, and a lack of guidelines for safeguarding their access. This study was carried out to increase understanding of the interaction and potential for conflict between local uses and logging of these species, particularly on timber concessions, in order to provide a foundation for designing plans to safeguard the access of local people to NTFPs from timber species. This was done through interviews and participatory mapping of the trees from which villagers living near or within timber concessions collect wild foods.

Previous studies in DR Congo (Termote et al., 2012) and Cameroon (Fungo et al., 2016), have documented that forest foods can mitigate health disorders related to inadequate intake of nutrients, if consumed in adequate amounts. This study focused on three "conflict-of- use" species that provide important food products to villagers and are also valuable timber sources, and thus targets of logging operations. The species selected were Moabi or African Pearwood (Baillonella toxisperma), Sapelli or Sapelli Mahogany (Entandrophragma cylindricum), and Tali or the Forest Ordeal Tree (Erythrophleum suaveolens). Moabi produces an edible fruit and seed-oil, which are both consumed and sold (Mapaga et al., 2002). It occurs at low densities and is also considered vulnerable to extinction (White, 1998), but accounted in 2005 for close to 200,000 cubic meters of timber annually to the export market (Louppe, 2005). Sapelli hosts Imbrasia (Nudaurelia) oyemensis, one of the 82 species of caterpillars and larvae commonly consumed in Central Africa (Lewis, 2001; N'Gasse, 2004). It is also the second most important timber species in terms of volume exported from the region, contributing 1.3 million cubic meters of wood annually to the export market (Bayol et al., 2012), and is considered vulnerable to extinction as a result of this level of demand (Hawthorne, 1998). Another edible caterpillar, Cirina forda, feeds on Tali (Balinga et al., 2004; N'Gasse, 2004; Vantomme et al., 2004; Hoare, 2007), which accounted for around 200,000 cubic meters of timber annually for the export market in 2012 (Bayol et al., 2012), and as of 2015 , accounted for $31 \%$ of the volume of export timber produced in Cameroon (Cerutti et al., 2016). Forestry regulations 
in Cameroon define minimum diameters for trees to be felled: $100 \mathrm{~cm}$ for Moabi and Sapelli and $50 \mathrm{~cm}$ for Tali. Only trees larger than these sizes can be logged legally (MINFOF, 2005).

These three species are all important to the nutrition of local people. Moabi oil provides fats and other bioactive compounds (Fungo et al., 2015). Caterpillars are rich in proteins: flour made from Imbrasia oyemensis was $58 \%$ protein and $24 \%$ fats while Cirina forda contains $14 \%$ protein, a proportion similar to beef. Caterpillars are also rich in micronutrients, providing essential vitamins and fatty acids (Amon et al., 2009). These local food resources are very important complements to their agricultural crops for villagers in these areas (Lewis, 2001). The rural population of Cameroon is food-insecure, chronically undernourished. and poor, with very limited options for buying food (Fungo et al., 2016, 2020). It has been well-documented that around the world, women and men use, know about and benefit differently from forest resources (Colfer et al., 2016). Women are also primarily responsible for using forest foods to feed their families (Fungo et al., 2016). This study was designed to be able to evaluate gender differences in the collection and use of these resources.

The study objective was to contribute to knowledge about the collection of wild food resources by villagers, specifically to determine: (1) what are the practices of collection and use, and their benefits, and how do these vary between men and women?; and (2) do local people obtain food resources from timber concessions; and to what degree is their access to these resources threatened by logging?

\section{STUDY SITES AND METHODS}

\section{Study Sites}

This study was carried out in two villages in the vicinity of each of two forest concessions in Cameroon, Fabrique Camerounaise de Parquet (FIPCAM) in the South region and Societé Camerounaise de Transformation du Bois (SCTB) in the East region, each over $150 \mathrm{~km}$ from Yaoundé (Levang et al., 2015; Figure 1). The population around the FIPCAM concession was estimated at 79,353 in 2009, living in 29 villages and hamlets (EnviroConsulting, 2009). Nearly all were of the Bulu (Bantu) ethnic group (Levang et al., 2015). In 2004 the population around the SCTB concession numbered about 25,783 people who lived in 41 villages and hamlets and were mainly of the Kako, Pol and Maka (Bantu), and Baka (pygmy) ethnic groups (Medinof, 2004). Population density around the concessions was low, with 13.4 inhabitants $/ \mathrm{km}^{2}$ in the South and 7.1 inhabitants $/ \mathrm{km}^{2}$ in the East (Levang et al., 2015). Socio-economic data collected in villages around the concessions determined that in the South, $67 \%$ of households collected caterpillars and $8 \%$ collected Moabi fruits, as compared to $24 \%$ who reported collecting caterpillars and $51 \%$ who collected Moabi fruits in the East. Households have higher average income in the south, in large part from production and sale of cacao, although informal logging is important to a few households (Levang et al., 2015).

This was one of an array of studies about timber and non-timber resource use in timber concessions, carried out by an interdisciplinary team of researchers including the authors, all participating in a single research project. Sample villages were selected because they were in close proximity to a forest concession which was actively felling trees and because parallel and complementary studies of consumption and use of forest products and the impacts of logging were taking place in those concessions and those villages [i.e., socioeconomic studies described in Levang et al. (2015); nutritional studies described in Fungo et al. (2016); and ecology studies including quantification of the density of resource trees, described in Noutcheu et al. (2016)]. In addition, villages were selected that had a relatively small population and number of households that were spatially compact. This facilitated mapping of the spatial patterns of collection activities.

The two sample villages near the FIPCAM concession (Ngone and Meyos), are inhabited by Bulu people. Their principal activities are agriculture, hunting and informal timber production. These two villages are very near the concession; many of their fields and plantations of cocoa and plantain are actually located within the current concession boundaries (Noumbissi, 2012). Around the SCBT concession, Nkolbikon village is inhabited by Baka people who depend to a very high degree on forest resources, as they have not traditionally practiced agriculture [(Tieguhong and Ndoye, 2007); but see Levang et al. (2015)]. The village is located inside a formally established community forest that is located $<5 \mathrm{~km}$ from the concession's annual cutting area of 2012. Community forests in Cameroon are managed under an arrangement whereby the communityor groups within the community-have the rights to harvest and sell the timber and the revenues are supposed to be distributed to the whole community (WRI, 2005). Another sample village, Ndembo, is inhabited by Kako and Pol people (Bantu).

\section{Field Data Collection}

The study was based on participatory resource mapping combining key informant interviews with GPS positioning and measurement of collection trees to which they guided the researchers. Data was gathered by two teams, each consisting of three people: a researcher, an informant and a local guide for translating and clearing paths where necessary. Each team was equipped with a Garmin Dakota 20 GPS device, a diameter measuring tape, field data sheets, and a survey instrument with 21 questions concerning the availability, seasonality, and access rights to resources, and the gendered roles in collection, transformation, and sale of the NTFPs (see Appendix 1). Some questions addressed the participation of children, but children were not involved in the research process.

To take into account that women and men have different interests in resources and approaches to using them, the teams were gender-differentiated: in one team, a female researcher accompanied a female collector/informant; in the other, a male researcher accompanied a male collector/informant. This was to: (a) ensure that responses reflected women's and men's knowledge and interests; (b) collect information about NTFP collection which could be gender-disaggregated; and (c) alleviate concerns over male researchers' accompanying female villagers on daylong walks in the forest. 


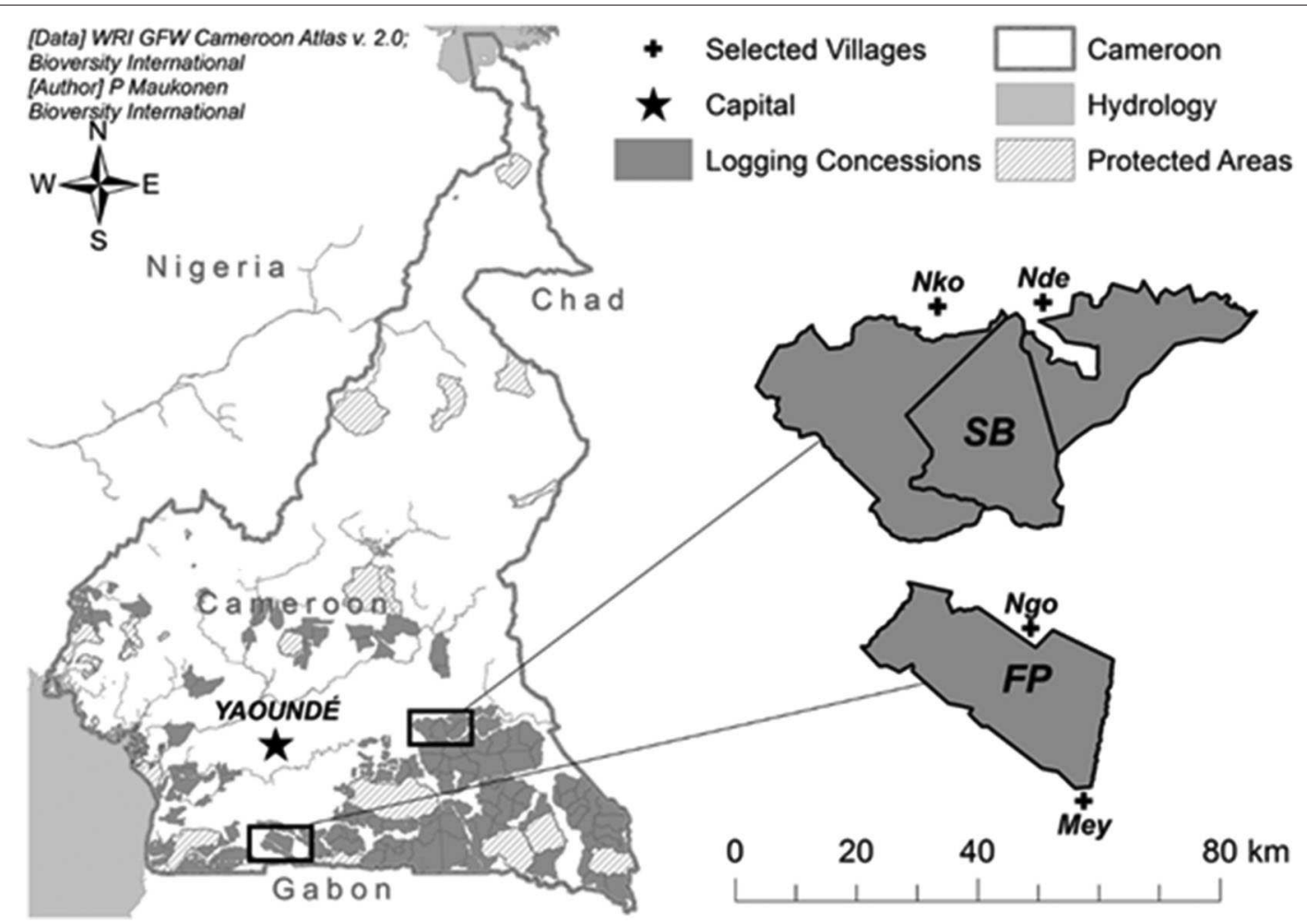

FIGURE 1 | Map of the two selected logging concessions in Cameroon (SCTB and FIPCAM) and the two adjacent villages selected for study next to each one. [Data: World Resources Institute and Bioversity International].

A different informant/guide was selected each day for a period of 5 days in each village, making a total sample size of five men and five women from each village, a total of 20 men and 20 women across the two concessions. Informant/guides were chosen during open meetings carried out in each village, where the study was described and individuals interested in participating were asked to raise their hands to volunteer. During the same meetings, researchers made arrangements with the volunteer informants to set up mutually convenient times to carry out the mapping. Each informant guided the researcher to the Moabi, Sapelli, and Tali trees from which they collected either fruits or caterpillars during day trips. At each tree the researcher would identify the species, measure the diameter at breast height (dbh) and determine the geographical coordinates of the tree. Then he/she would ask the collector a series of nine questions concerning the productivity of and access rights to the tree. The remaining 12 questions, concerning the transformation and sale of the NTFPs, were posed throughout the day (see Appendix 1). Field work was conducted from the end of February to the end of March.

\section{Analysis}

Coordinates of the villages and the trees were downloaded from the GPS devices in text format using DNRGPS, and exported to LibreOffice Calc (4.1.6), where additional variables were added from the responses to questionnaires. These included: (1) the dbh (important for determining which trees had a diameter greater than the legal felling diameter); (2) the gender(s) of the collectors who visit the tree; (3) whether the tree was visited as part of a planned excursion to collect this resource, or whether it was visited in connection with other activities; and (4) observations of changes in abundance of the NTFP over the last 5 years.

This data was saved as comma-separated values (*.csv) and read by RStudio ( 0.98 .501 with $\mathrm{R}$ i386v 3.0.0). The distance between villages and trees was calculated by programming the Haversine distance formula, along with classification of distance intervals $(0-1 \mathrm{~km}, 1-2 \mathrm{~km}$, etc.) and an indicator of whether the dbh was greater than the legal felling diameter. Analysis of Variance (ANOVA) and General Linear Model (GLM) analyses were carried out to evaluate the relationships between the distance to the trees from the village, the gender of the collector and the tree species. Chi-squared analyses were used to examine the relationships between the count of trees and distance intervals, planning of collection trips, and dbh classes. Questionnaire data was analyzed as averages of the responses given by the informants. Figures were produced using the ggplot 2 package.

Polygons indicating logging concession boundaries were sourced from the World Resources Institute Global Forest Watch Cameroon Atlas v.2 and polygons indicating the extent of the humid dense forests of the Congo Basin were sourced from the World Wildlife Foundation. Villages and the trees from which NTFPs were collected were mapped using ArcGIS (10.0). Determining whether trees fell within or outside logging 
concession boundaries was done by joining the attribute tables of the tree points with the concession polygons in ArcGIS; and the resulting data was added as a variable in the.csv dataset.

\section{RESULTS}

\section{Where, When, and How Do Men and Women Collect, Use, and Benefit From Wild Food Resources?}

A total of 188 trees of the three selected species were visited around the four sample villages (Table 1). Trees to which people made 1-day trips for NTFP collection were mostly between 1 and $5 \mathrm{~km}$ from the village, with $5 \%$ of the trees recorded further than $5 \mathrm{~km}$ away, and $13 \%$ recorded closer than $1 \mathrm{~km}$ (Figure 2). Different patterns of resource collection were recorded for men and women. Men visited trees that were further from the village (up to $6.2 \mathrm{~km}$ ) than those visited by women (up to $3.8 \mathrm{~km}$ ) (ANOVA, $\left.F_{(4.02)}, p=0.004\right)$. Post hoc comparisons using the Tukey HSD test indicate that the average distance to trees visited by men was longer (averaging $3.52 \mathrm{~km}$ ) than the distance to trees visited more frequently by women and children (0.99$2.23 \mathrm{~km}$ ) (Table 2, Figure 3). The mean distance to trees from which women and children collect was significantly different from the mean distance to trees visited by men, and combinations of men and women; but other paired comparisons did not reveal significant differences.

The collection of these products was not found to be a genderspecific activity: most trees, in all four sample villages, were visited by both men and women $\left(\chi^{2}=125.3, \mathrm{df}=4, p<0.0001\right)$ (Table 2). Only $4 \%$ of trees were reported to be visited only by men and $9 \%$ only by women. However, the processing and transformation of caterpillars (which are dried and smoked for preservation) and Moabi seeds to oil was found to be dominated by women.

The fruits of Moabi are collected from July to September, with a peak season in August. Interviews with 22 key informants in the villages indicated that the primary use of the fruits is to extract seed-oil, which the collectors both consume and sell. Extraction of the oil from the seeds is predominantly done by women ( $95 \%$ of responses), although men in Nkolbikon and Ngone (23\% of responses), and children in Ngone (5\% of responses) play a role in at least one stage of this transformation process. Informants reported consuming on average $2 / 3$ of the seed-oil produced and selling $1 / 3$, but the proportions varied among villages. Respondents in Ngone and Meyos reported that they sold, respectively, an average of 17 and $3 \%$ of the seed oil that they produced. Respondents in Nkolbikon reported selling an average of $49 \%$, and those in Ndembo reported selling an average of $60 \%$ of the oil they produced.

According to informants, Moabi seed oil is sold mainly on the village roadside, to traveling merchants who purchase the oil for markets outside the local area (73\% of responses), although $41 \%$ of respondents also reported traveling to other nearby villages to sell the oil. According to the respondents, the demand for oil has either stayed the same over the last 5 years $(45 \%)$ or increased (55\%); however the availability of seed-oil has reportedly either stayed the same over the last 5 years $(23 \%)$ or decreased $(50 \%$ of respondents). The $27 \%$ of respondents who reported an increase in the availability of oil were only in the village of Meyos. Respondents indicated that seed oil was sold at an average price of 2200 FCFA (USD \$4.25)/liter whereas their responses regarding average revenues derived from the sale of a tree for timber ranged hugely but averaged FCFA 60,240 ( USD \$120, Table 3).

According to the respondents, caterpillars from Sapelli are collected in August and the caterpillars from Tali are collected between March and April. The two species of caterpillars were combined in the analysis as the consumption, sale, and revenues derived from both species were reported to be the same, regardless of the different collection times. The informants were asked what proportion of the caterpillars they consumed and what proportion they sold. On average respondents reported consuming $2 / 3$ of the caterpillars, and selling $1 / 3$, however this response varied among villages. On average, respondents in Ngone reported selling only $7 \%$ of the collected caterpillars; respondents in Nkolbikon reported selling 23\%; those in Ndembo reported selling 38\%; and informants in Meyos reported selling $51 \%$. Caterpillars were reported to be cooked or smoked before consumption and sale, and this work was reported to be conducted by women ( $95 \%$ of respondents). Only $5 \%$ of respondents in Nkolbikon and Ngone reported that men and children played roles in the processing and transformation of caterpillars.

Half of the respondents reported selling caterpillars locally and $55 \%$ to traveling merchants. Of the respondents, $36 \%$ reported traveling to neighboring villages to sell caterpillars; however all of these respondents were from Nkolbikon and Ndembo. The market demand for caterpillars has stayed the same over the last 5 years according to $77 \%$ of respondents, and increased according to $23 \%$, with no respondents indicating a decrease in the demand. At the same time $73 \%$ of respondents indicated that the availability of caterpillars had decreased over the past 5 years, and $18 \%$ reported that it had stayed the same. Only $9 \%$ of respondents, all in Meyos, reported an increase in the availability of the resource over recent years.

Where sold, the caterpillars are reported by respondents to fetch a price of $\sim$ FCFA 700 per liter $( \pm 350)(\sim$ USD $\$ 1.40)$. Although the two caterpillar species were grouped as a single resource, the timber from the trees hosting the two species has very different values. The local sale of a sapelli tree was reported to provide average revenues of FCFA 90,140 ( USD $\$ 180$ )/tree, whereas the sale of a Tali tree would only provide an average of FCFA 17,100 ( USD \$ 34). In both cases, the ranges of estimates varied by orders of magnitude (FCFA 3,000300,000 for Sapelli and FCFA 1,500-50,000 for Tali) (Table 3). This range may reflect the variation in price received by different participants in the value chain, from the low $7 \%$ remuneration provided to the customary tree owner, to the chainsaw miller's selling price of just over FCFA 17,000 per cubic meter (EUR 26 in literature), reported by Lescuyer et al. (2012). It is noteworthy that these values are only about $20 \%$ of the sale value of trees felled for export by industrial concessionaires (Cerruti and Lescuyer, 2011).

The frequency of responses indicating that collection trips were organized specifically to gather these resources, varied among the villages ( $\left.\chi^{2}=12.501, \mathrm{df}=3, p=0.006\right)$ (Figure 4). 


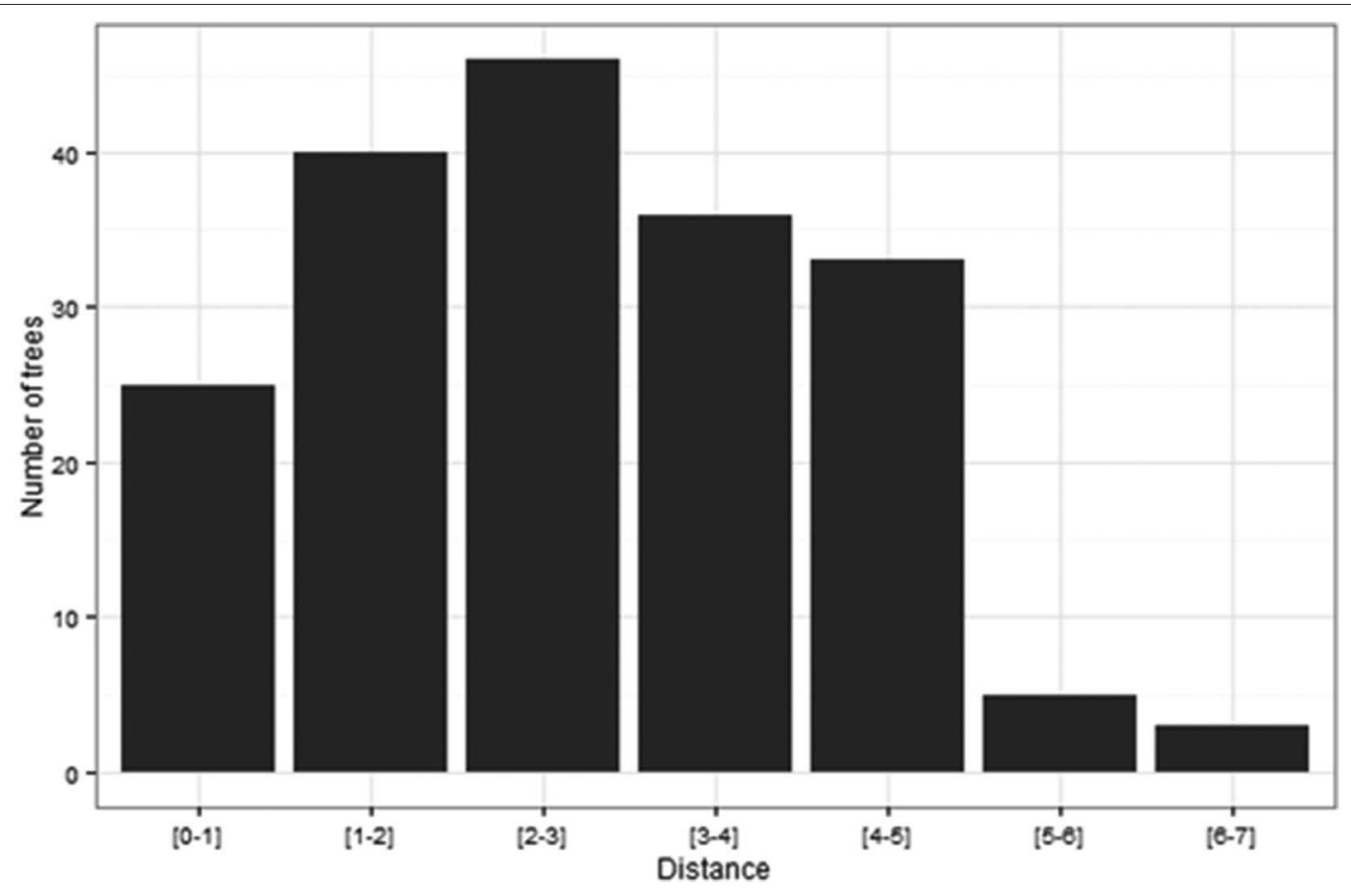

FIGURE 2 | Number of trees located within $1 \mathrm{~km}$ distance bands from the village (all four villages, all three species).

TABLE 1 | Number of collection trees of each species visited with informants from each sample village.

\begin{tabular}{lcccc}
\hline & Moabi & Sapelli & Tali & Subtotal \\
\hline Meyos & 13 & 11 & 14 & 38 \\
Ndembo & 8 & 20 & 16 & 44 \\
Ngone & 9 & 11 & 3 & 23 \\
Nkolbikon & 32 & 27 & 24 & 83 \\
\hline Total & 62 & 69 & 57 & 188 \\
\hline
\end{tabular}

The number of trees visited on trips carried out specifically for that purpose corresponded to $81 \%$ (67) in Nkolbikon, $70 \%$ (31) in Ndembo, 67\% (22) in Meyos, and 48\% (11) in Ngone. Organizing specific collection trips, as opposed to collecting opportunistically or in passing, was common with all three species, but especially widespread with regards to gathering of fruits of Moabi $\left(\chi^{2}\right.$ $=19.27, \mathrm{df}=2, p<0.001$ ) (Figure 5). The collection of $I$. oyemensis was generally focused on this objective, but slightly less commonly than the collection of Moabi fruits. Half of respondents reported organizing collection trips specifically to collect C. forda caterpillars and half reported that they did not.

All three resources were collected in all of the villages, however the number of trees visited with the informant collectors varied among villages (Table 1) $\left(\chi^{2}=41.75 \mathrm{df}=3, p<\right.$ 0.001). Collectors visited trees at distances from the villages that ranged from $150 \mathrm{~m}$ to $6.2 \mathrm{~km}$, and these distances were
TABLE 2 | Average, minimum and maximum distances from villages to trees according to the gender and maturity of collectors among 4 villages.

\begin{tabular}{lcccc}
\hline \multirow{2}{*}{ Gender of collector } & \multirow{N}{*}{$N$} & \multicolumn{2}{c}{ Distance from village to trees (km) } \\
\cline { 3 - 5 } & & Avg. & Min. & Max. \\
\hline Men & 8 & $3.52( \pm 2.37)$ & 1.36 & 6.24 \\
Men+Women & 69 & $2.99( \pm 1.11)$ & 0.59 & 5.01 \\
Men+Women+Children & 90 & $2.58( \pm 1.53)$ & 0.15 & 5.49 \\
Women & 16 & $2.23( \pm 0.87)$ & 0.92 & 3.79 \\
Women+Children & 5 & $0.99( \pm 0.93)$ & 0.32 & 2.59 \\
\hline Total & 188 & $2.70( \pm 1.42)$ & 0.15 & 6.24 \\
\hline
\end{tabular}

significantly different among the four villages (ANOVA, $F_{(43.23)}$, $p<0.001$ ) (Figure 6). The only distances that were not significantly different from one another (post-hoc Tukey HSD test) were Meyos and Ngone, the two villages which recorded the shortest distances at which trees were visited. Ninety-one percent of the collection trees in Ndembo and $82 \%$ of collection trees in Nkolbikon were at distances $>2 \mathrm{~km}$, but in Ngone and Meyos the vast majority of trees from which resources were collected occurred $<2 \mathrm{~km}$ from the village.

\section{Do People Collect From Timber Concessions, and Are Their Resources Threatened by Logging?}

On average, only $14 \%$ of all the trees visited with collectors were located within neighboring logging concessions, but the 


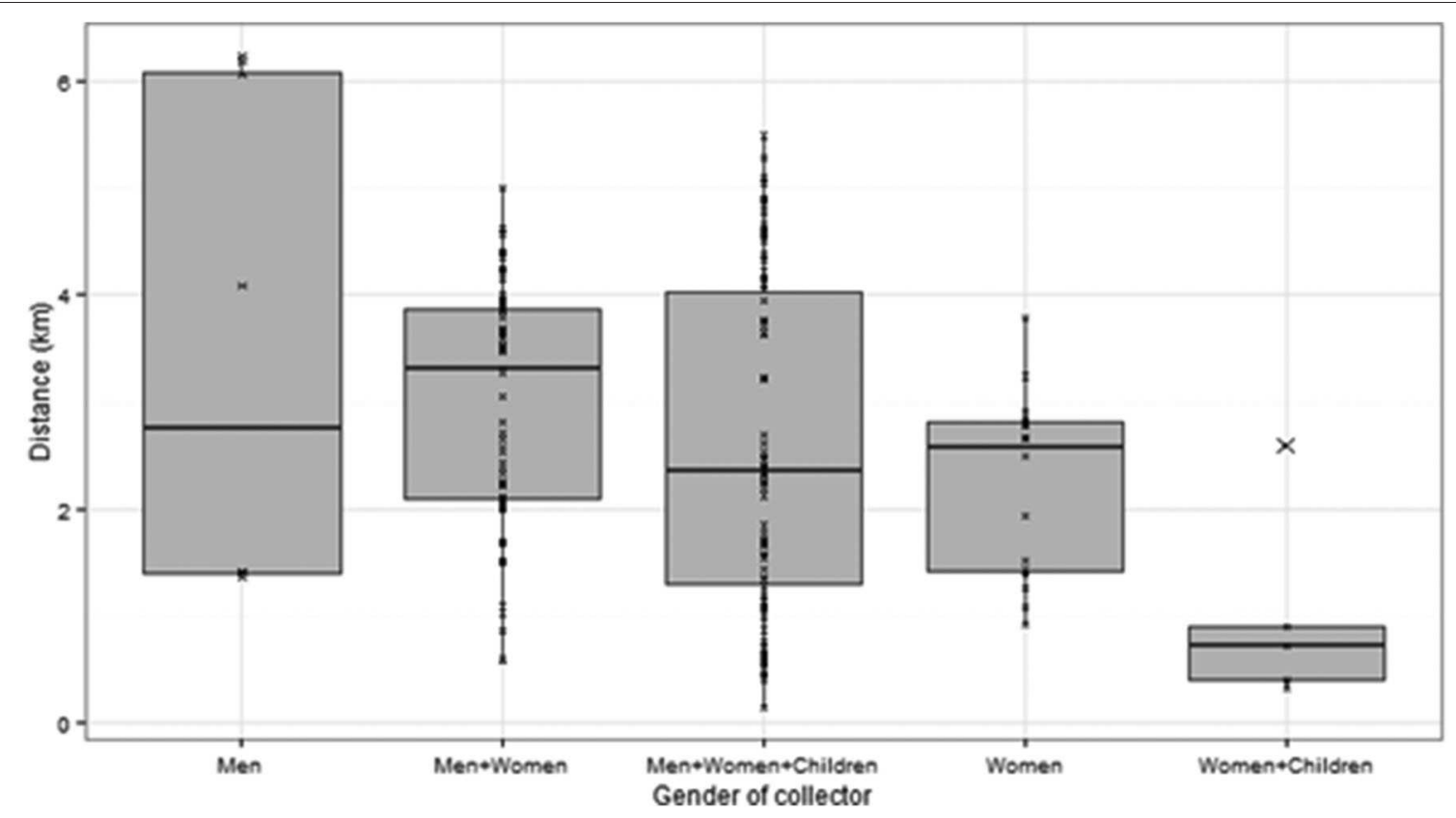

FIGURE 3 | Distances between villages and trees by gender of the collector, combining all four villages.

TABLE 3 | Average value of oil, caterpillars and their source trees, when sold; information from this study except where footnoted.

\begin{tabular}{|c|c|c|c|c|c|}
\hline Species & Product & $\begin{array}{l}\text { Average Sale Value per tree } \\
\text { product ( } 500 \text { FCFA per USD) }\end{array}$ & $\begin{array}{l}\text { Estimated annual } \\
\text { production per tree }\end{array}$ & $\begin{array}{l}\text { Estimated sale value of } \\
\text { NTFP per tree per year }\end{array}$ & Comments \\
\hline Moabi & Seed oil & $\begin{array}{l}\text { FCFA 2,200 ( } \pm \text { 680) ( USD } \\
\$ 4.25) \text { per liter }\end{array}$ & 150 liters & $\$ 638$. USD $^{\mathrm{a}}$ & $\begin{array}{l}\text { Fruiting takes place every three years } \\
\text { after trees reach } 50 \mathrm{~cm} \text { diameter }{ }^{a}\end{array}$ \\
\hline Sapelli & $\begin{array}{l}\text { Caterpillars (I. } \\
\text { oyemensis) }\end{array}$ & $\begin{array}{l}\text { FCFA } 700 \text { per liter }( \pm 350) \\
(\sim \cup S D \$ 1.40)\end{array}$ & 25 liters dry weight ${ }^{\mathrm{b}}$ & $\$ 35$ USD & Caterpillars are sold dried, smoked \\
\hline Tali & $\begin{array}{l}\text { Caterpillars (C. } \\
\text { forda) }\end{array}$ & $\begin{array}{l}\text { FCFA } 700 \text { per liter }( \pm 350) \\
(\sim \cup S D \$ 1.40)\end{array}$ & 20 liters dry weight ${ }^{b}$ & \$28 USD & Caterpillars are sold dried, smoked \\
\hline Sapelli & Timber & $\begin{array}{l}\text { FCFA 90,140 ( USD \$180) per } \\
\text { tree }\end{array}$ & & & $\begin{array}{l}\text { Range of responses: FCFA } \\
3,000-300,000\end{array}$ \\
\hline Tali & Timber & $\begin{array}{l}\text { FCFA } 17,100 \\
\text { ( USD \$34) per tree }\end{array}$ & & & $\begin{array}{l}\text { Range of responses: FCFA } \\
1,500-50,000\end{array}$ \\
\hline
\end{tabular}

${ }^{a}$ Calculated using yields presented by Schneemann (1995).

${ }^{b}$ Annual yields of edible caterpillars quantified in the Democratic Republic of Congo averaged $11.4 \mathrm{~kg}$ fresh weight of $\mathrm{l}$. oyemensis from each sapelli tree $\geq 80 \mathrm{~cm}$ dbh and $9.1 \mathrm{~kg}$ of $\mathrm{C}$.

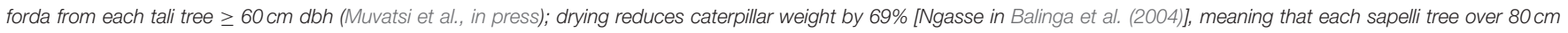

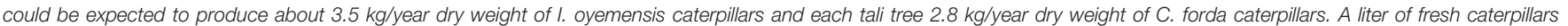

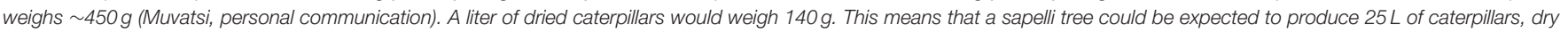
weight/year; and a tali tree about $20 \mathrm{~L}$ of caterpillars/year. At a sale price of USD \$1.40, this would be worth \$35 USD and \$28/year, respectively.

percentage varied by species and by village. None of the trees visited with collectors from Nkolbikon were in the concession, while $38 \%$ of those visited with collectors from Ndembo were. Seven out of eight of the Moabi trees visited by collectors from Ndembo and two out of three Tali trees visited with collectors from Ngone were located within logging concessions (Table 4, Figures 7, 8). Trees within logging concessions were visited more frequently by certain gender groups $\left(\chi^{2}=\right.$ 15.6549 , $\mathrm{df}=4, p$-value $=0.004)$, presumably due to the distances to which these groups travel to collect resources.
Half of the trees reported to be visited exclusively by men (4) were located within logging concessions, whereas 20\% (14) of the trees visited by men and women, and 19\% (3) of the trees visited by women were within logging concessions. Only $7 \%$ (6) of the trees visited by men, women, and children together were inside logging concession boundaries, and no trees inside logging concessions were visited by women and children.

The majority of the trees recorded within the logging concessions (78\%) exceeded the minimum commercial 


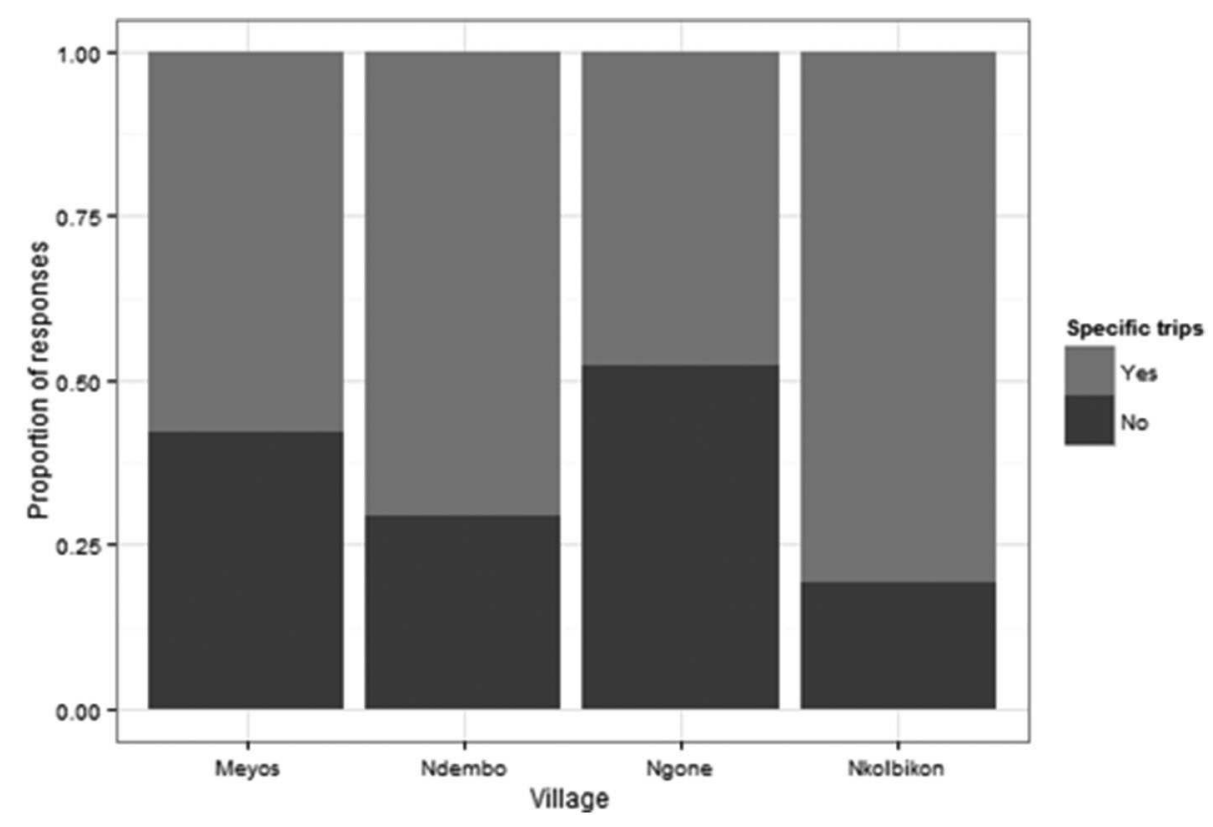

FIGURE 4 | Proportion of trees for which collection is organized for that purpose, by village.

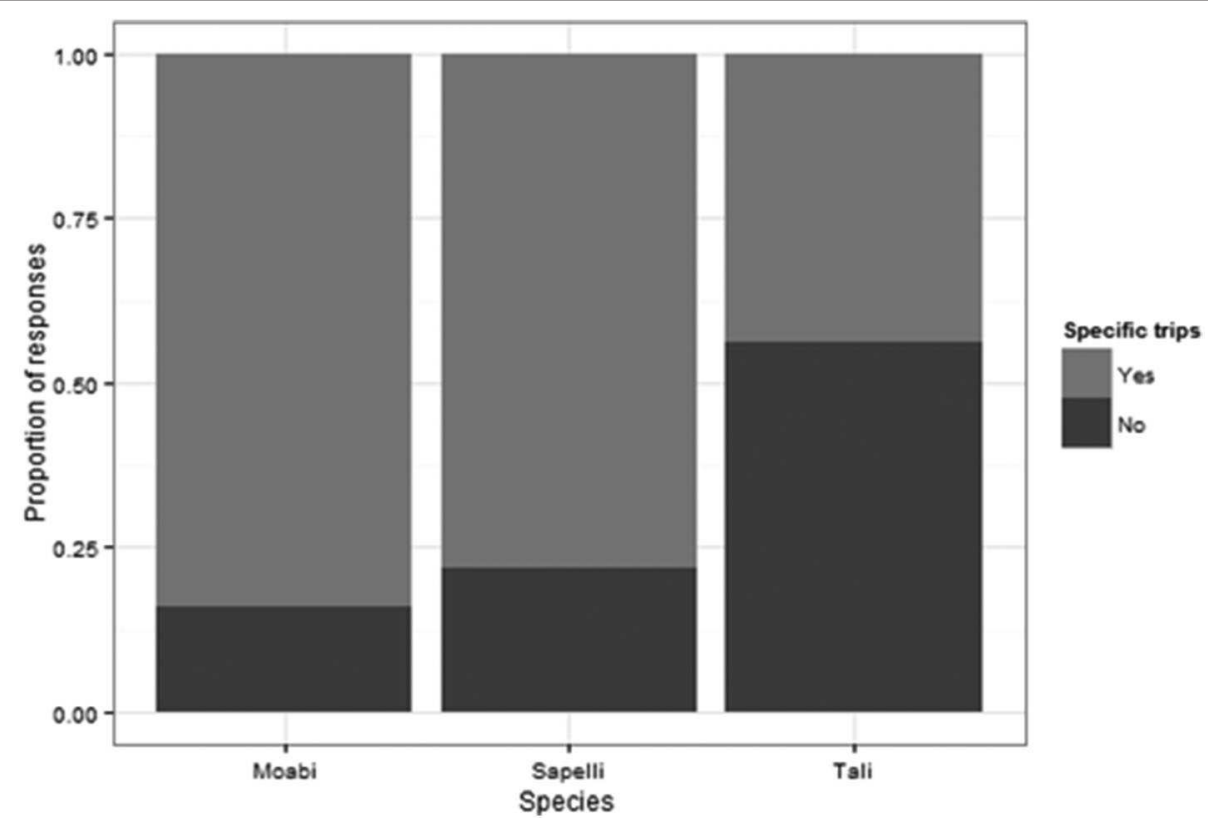

FIGURE 5 | Proportion of trees of each species for which collection is organized for that purpose, among all four sample villages.

felling limits of $100 \mathrm{~cm}$ for Moabi and Sapelli and $50 \mathrm{~cm}$ for Tali (MINFOF, 2005) (Figure 9). In fact, although the diameters of the recorded trees showed large ranges (Moabi $45-341 \mathrm{~cm}$; Sapelli $63-355 \mathrm{~cm}$; and Tali $54-237 \mathrm{~cm}$ ), the majority of the collection trees visited exceeded their legal felling diameter $\left(\chi^{2}=17.74, \mathrm{df}=2, p=0.0001\right.$; Figure 9).

\section{DISCUSSION}

Are There Differences in Women's and Men's Collection and Use of Wild Food Resources?

Two key differences were documented between men's and women's practices of collection and use of the three food 


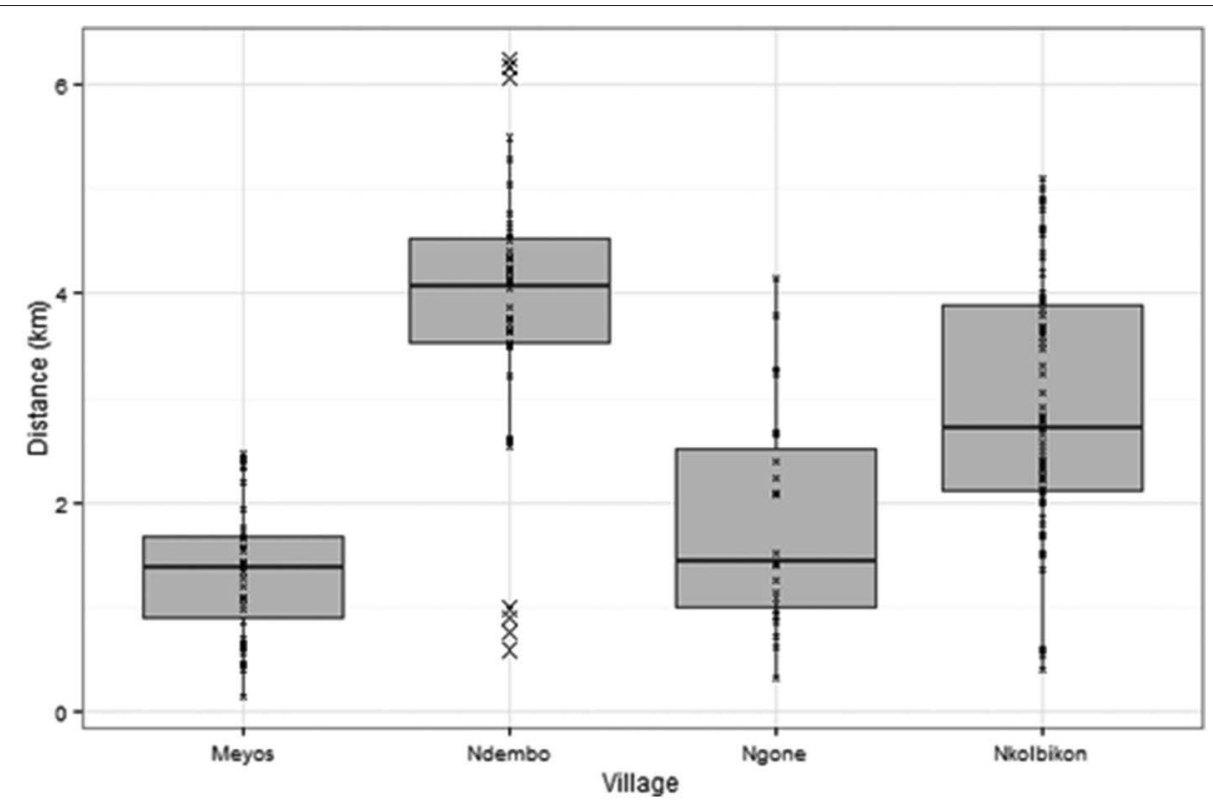

FIGURE 6 | Distance between the village center and trees from which food resources were collected, among all four sample villages.

TABLE 4 | Number and percentage of visited trees of each species located within logging concession boundaries around each of the sample villages.

\begin{tabular}{lccccc}
\hline Moabi & Sapelli & Tali & $\begin{array}{c}\text { Percent } \\
\text { collection } \\
\text { trees/village }\end{array}$ & $\begin{array}{c}\text { Total } \\
\text { collection } \\
\text { trees } \\
\text { visited/village }\end{array}$ \\
\hline Meyos & $1(8 \%)$ & $1(9 \%)$ & $1(7 \%)$ & $3(8 \%)$ & 38 \\
Ndembo & $7(88 \%)$ & $6(30 \%)$ & $4(25 \%)$ & $17(38 \%)$ & 44 \\
Ngone & $3(33 \%)$ & $2(18 \%)$ & $2(67 \%)$ & $7(30 \%)$ & 23 \\
Nkolbikon & $0(0 \%)$ & $0(0 \%)$ & $0(0 \%)$ & $0(0 \%)$ & 83 \\
\hline Total & $11(18 \%)$ & $9(13 \%)$ & $7(12 \%)$ & $27(14 \%)$ & 188 \\
\hline
\end{tabular}

resources studied. In all villages, women were reported to be the ones primarily responsible for transforming Moabi fruits, and caterpillars, echoing what has been found for other NTFPS and in other studies (Ndoye et al., 1997; Ingram et al., 2014). The second key difference was the greater distances traveled by men to collection trees as compared to the distances traveled by women and children. These differences reflect, in part, the spatial distribution of other gender-specific activities in the forest which coincide with the location of the tree, for example hunting, fishing, specific agricultural activities, and gendered division of household labor. For example, women are the family fishers, as reported by informants in the villages and in literature (Vantomme et al., 2004). Women more often collect from trees which are close to popular fishing venues. Women are responsible for tending to the household and feeding the family, so their collection of NTFPs with their children is typically in the immediate vicinity of the village. Both men and women have roles in various stages of agricultural production (Sunderlin and
Pokam, 2002), so both would be expected to collect from trees close to their farms or smallholdings, which are usually situated in areas which are accessible to the village. Discussions with the informants generally indicated that children would not venture to the forest on their own, though they often accompanied their mothers. The fact that informants did not indicate many trees from which groups of men and children collected fruits or caterpillars may be explained because these trees were relatively far from the village. A relatively few distant trees were visited for NTFP collection, and these were almost exclusively visited by men. They were typically found close to more "undisturbed" areas in the forest where men commonly hunt, as reported by Ingram et al. (2014).

\section{Organized Trips or Opportunistic Collection?}

While many food resources were collected in connection with other activities, for example fishing, visiting agricultural plots, or hunting, some resources were collected during daily excursions carried out for that purpose. Moabi fruits are both heavy and valuable (Asseng Ze, 2008). Moabi oil was formerly the only oil source available to local people. Furthermore, Moabi trees commonly fruit only every 3 years (Cerruti and Lescuyer, 2011). All these features make it logical that collecting trips would be made specifically to collect Moabi fruits. Informants reported that only the elderly and small children stay in the village during these Moabi collecting expeditions. They are left behind due to the sometimes difficult terrain and long distances, and the fact that transporting fruits, and seeds back to the village from the forest requires a degree of strength that only adults and adolescents possess. There were reports in one village that young children do not collect Moabi regardless of the 


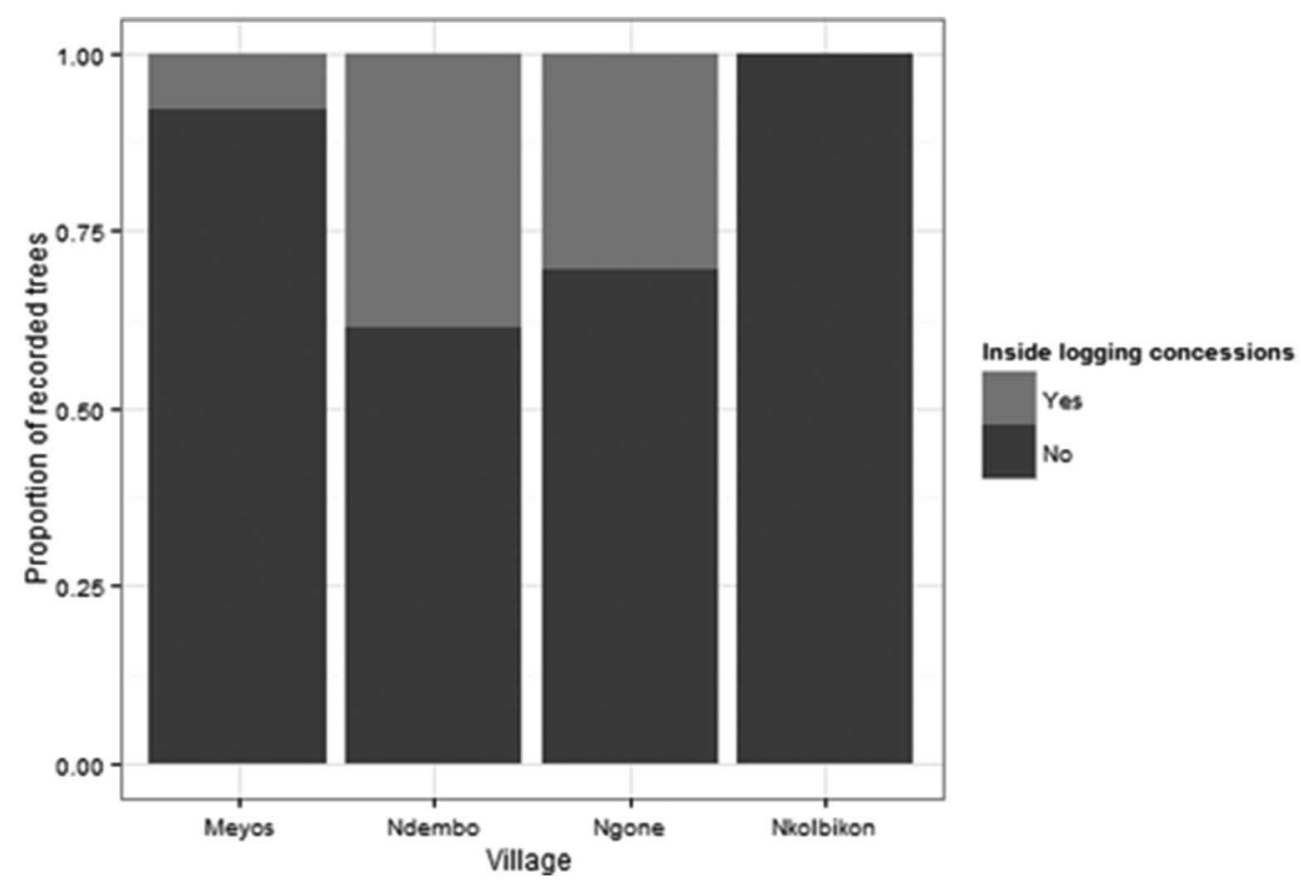

FIGURE 7 | Proportion of trees of each species which are located within logging concession boundaries, for all four villages.

distance, due to the mortal danger of head injuries caused by falling fruits. Caterpillars are easier than Moabi fruits/seeds to carry in large quantities or in addition to other products such as agricultural produce, fish, or bush meat; therefore special excursions may not always be necessary for their collection. Fewer respondents indicated that they made trips specifically to collect C. forda caterpillars than was the case for Moabi or $I$. oyemensis caterpillars. Although the informants reported that the two species of caterpillar are the same in terms of sales, there may be slight differences in their relative economic value (Ingram et al., 2014) or abundance; or preference, as not all respondents felt $C$. forda was as good to eat as I. oyemensis.

\section{Why the Differences Among Villages?}

Among the four sample villages, there were differences in the distances traveled to collect food resources and in the proportion of gathered foods that were consumed or sold. Differences in the distances traveled by collectors to obtain foods may have varied among villages because of the variation in the distribution and density of tree species around each village. Field surveys revealed that Moabi trees occurred at higher densities around Meyos than around any other villages (64.8/100 ha compared to about $19 / 100$ ha in Ngone and Nkolbikon). The lowest densities, 6.8/100 ha, were found around Ndembo, which also had the lowest density of tali trees of harvestable size-29.6/100 ha compared to 54.2$84.8 / 100$ ha around other villages (Noutcheu et al., 2016). It is not surprising, that collectors from Ndembo traveled the greatest distances to collection trees, and that more of the trees they collected from were located within the neighboring concession (Figure 6).
Ngone and Meyos are located next to the same logging concession in the South region of Cameroon. Discussions with the informants in this study and examination of maps revealed that the headquarters and main entrance of the FIPCAM concession had been located next to both of these villages in the two most recent operational contracts, whereas this was not the case in Nkolbikon and Ndembo. Proximity to these logging operations would provide opportunities for other forms of employment, lessening the dependence on forest resources. In the case of these four villages, people are likely to prioritize their activities not only according to the availability of products, but also according to the markets available to them and their cultural background, which would result in variation in the time they devote to NTFP collection and, as a consequence, in the distances they are willing to walk to obtain these products. It is likely that this is compounded by differences in men's and women's access to markets, and cultural or socio-economic differences which govern the customary use of certain products (Ingram et al., 2014). For example, a significant proportion of the population of Nkolbikon are Baka, who typically depend more on wildgathered resources than do other groups. They visited 32 Moabi trees, although the density of these trees around their village was considerably lower than the density around Meyos (where collectors took researchers to only 13 Moabi trees). In fact, collectors from Nkolbikon took researchers to many more trees, of all three species, than did collectors from the other villages (Table 1).

There were differences among villages in the proportion of oil used by the household or sold. Respondents in Nkolbikon and Ndembo, the two villages in the East, near the SCTB 


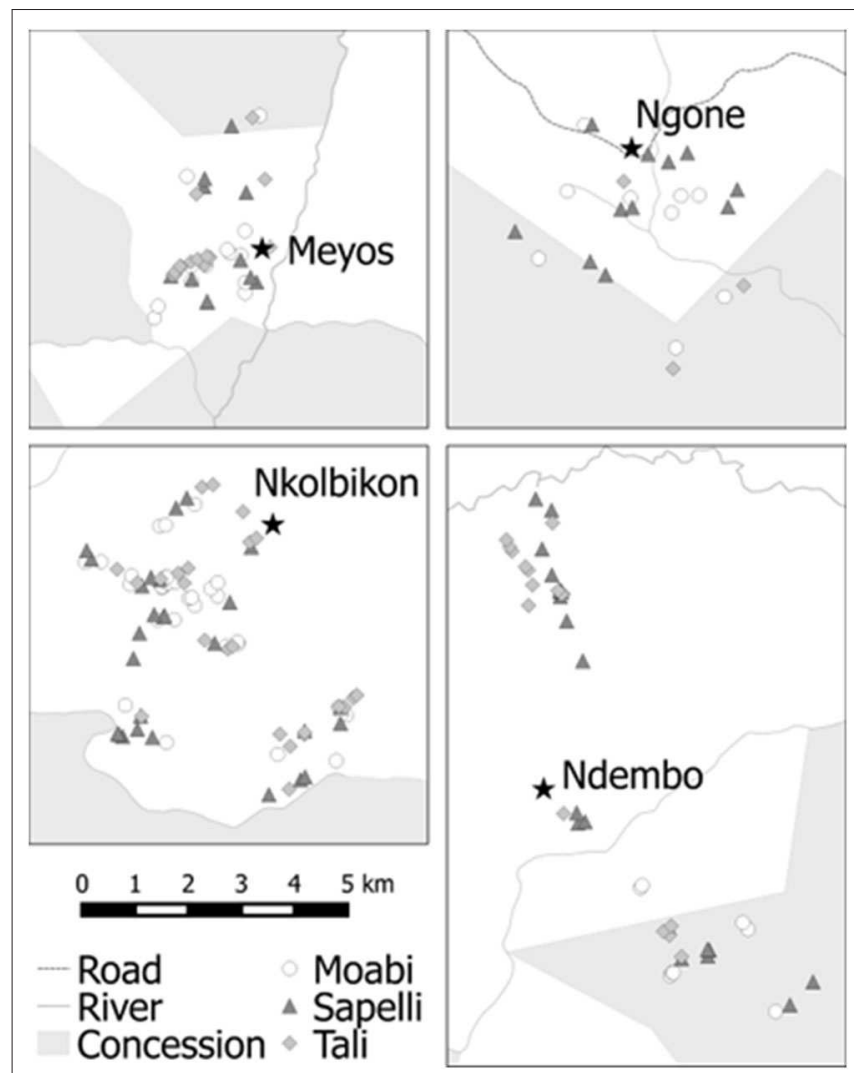

FIGURE 8 | Maps of the trees located around each of the four study villages, in relation to the forest concessions.

concession, reported selling half or more of the oil they produced as compared to respondents from Ngone and Meyos, in the South, near the FIPCAM concession, who reported selling only a small proportion, $<20 \%$. More than a third of the villagers from Nkolbikon and Ndembo also reported traveling to neighboring villages to sell caterpillars, which was not the case for villagers for Ngone and Meyos. Ndembo and Nkolbikon, in the East, near the SCTB concession, are more isolated than either of the villages around the FIPCAM concession, and have fewer alternative sources of income, meaning that the sale of gathered products from the forest is one of their few options for obtaining cash (Levang et al., 2015). Furthermore, villagers from Nkolbikon, many of whom were Baka, needed cash to buy agricultural goods, which they typically do not produce.

\section{Do People Collect From Concessions, and Is There a Conflict Between Logging and Collecting Food Resources?}

On average, only $14 \%$ of the trees which were visited on 1day collection trips were located inside logging concessions (Table 4). No limitations were put on the villagers with regards to collecting NTFPs from these trees. It turned out that all of these collection trees were located in areas defined as either conservation or regeneration zones, as designated in the SBCT concession management plan (MINFOF, 2005), or near village plantations located just inside the concession boundaries, which have been recognized by the FIPCAM concession management (EnviroConsulting, 2009). This implies that they are not immediately at risk of being felled. However, the great majority of these trees were of commercial felling size. This means they are potentially subject to a conflict of interest with regards to their value for timber to the concessionaires and their value for food resources to the villagers.

It may be that the abundance of collection trees has already been reduced by past logging. It is known that the areas managed by these two concessionaires have a history of prior exploitation by other companies, as far back as 1969 (Medinof, 2004), and possibly even before (ATIBT, 2007; Noutcheu et al., 2016). Most respondents expressed the opinion that the food resources from Moabi, Sapelli, and Tali trees had declined in abundance, and this is also reported in the literature. A study around four villages in the Mbang subdistrict showed that as of 1993, logging companies had extracted about $37 \%$ of the initial number of Moabi trees (as many as $86 \%$ around one village). As early as the 1990's, villagers were asking logging companies to stop felling this species, in some cases attaching boards to trees that indicated the name of the individual entitled to collect its fruits and in other cases arming themselves with bows and arrows to defend their trees (Schneemann, 1995). Another study determined that Cameroonian villagers' consumption of caterpillars declined after a logging company had extracted their host trees (Sapelli and others) (Asseng Ze, 2008).

Industrial logging, however, does not remove all individuals of any timber species. When trees have a high minimum cutting diameter, like Moabi and Sapelli, there is usually a large population of smaller trees in the forest that are not threatened with felling. It has been reported, however, that Moabi does not flower and fruit until it has reached $50-70 \mathrm{~cm}$ in diameter (Debroux, 1998), meaning that a relatively small proportion of trees below the legal felling diameter are likely to be important for fruit production. Sapelli and Tali trees below their felling diameters have been found to yield edible caterpillars, though at lower rates than larger trees (Muvatsi et al., in press). Because the cutting diameter for Tali is only $50 \mathrm{~cm}$, fewer trees of this species would be free from the risk of felling in industrial concessions.

However, even trees larger than the minimum cutting diameter may escape felling. A parallel study to this one carried out in the SCBT and FIPCAM concessions found that fewer than half of the Sapelli or Tali trees larger than the minimum commercial felling diameter were felled by timber concessionaires, either because they had poor form, or because they were located where they could not easily be extracted (Noutcheu et al., 2016). A similar pattern was found on concessions in the Democratic Republic of the Congo (Muvatsi et al., 2018). Current logging guidelines that require that seed trees be left standing during logging, should contribute to safeguarding some collecting trees (ATIBT, 2007). Similarly, logging guidelines that prohibit felling of trees within a band along rivers, on slopes above a certain steepness, or in inundated areas, 


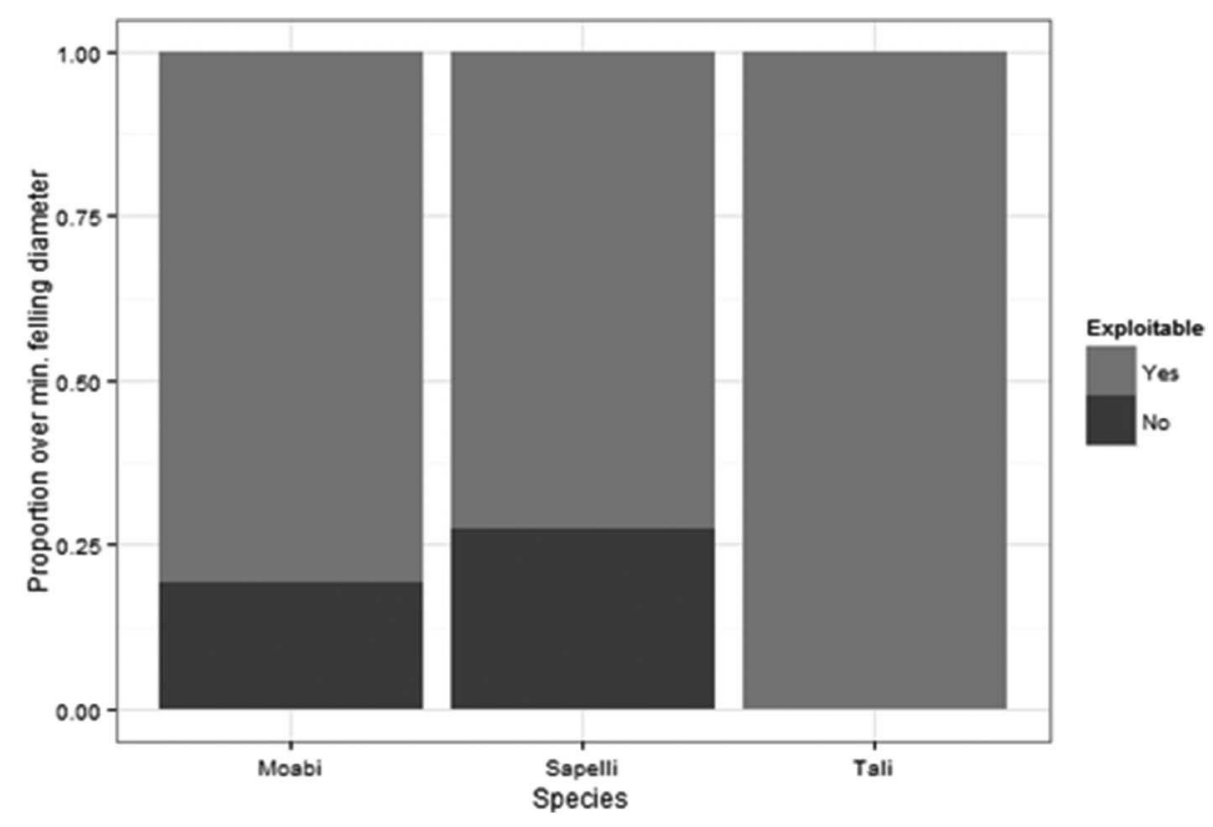

FIGURE 9 | Proportion of trees of each species which fall under or over the legal felling diameter, combining all four villages.

would all contribute to sustaining populations of trees that yield NTFPs.

To better visualize the spatial extent of the potential conflicts between timber harvesting and gathering of forest foods, we mapped the areas around villages that extended into timber concessions and calculated their areas. We used our average distance to collection trees of $2.7 \mathrm{~km}$ as a radius to represent the "resource shed." Applying this radius on a World Resources Institute spatial database of 4,115 villages located within the dense forest zone of Cameroon (as mapped by the World Wildlife Foundation), revealed that safeguarding these areas from logging would affect a total area of around 5.8 million ha, about $1 / 3$ of the 18.8 million ha of dense forest. This is a conservative estimate, given the maximum collection distances of over $6 \mathrm{~km}$ recorded in this study, and the fact that people go even further to collect on multi-day collection trips (Schneemann, 1995; Ingram et al., 2014; Levang et al., 2015). Of this total area, 335000 ha around 838 villages, would overlap with current logging concessions, and a further 89,000 ha would overlap with protected areas (Figure 10). This is a simplistic and generalized model, and like the proportions of household income derived from various land-uses, collection distances are likely to vary with the remoteness of the village and access to markets (Levang et al., 2015). However, this simple indicator that resource uses overlap gives support to the need for participatory forest management planning taking into account both non-timber and timber resources, and increased attention to shared resource governance in order to ensure equitable rights for local users, particularly for multiple-use/conflict-of-use species important for their wellbeing and livelihoods. Participatory mapping to define trees important to local people for the collection of edible caterpillars and other products has already been initiated, notably involving the Mbendjele pygmies on concessions held by the Congo and Congolaise Industrielle des Bois (CIB), a subsidiary of a Danish Group, which holds logging rights to $10 \%$ of the Congo (Hopkin, 2007).

Negotiations and agreements between concessionaires and villagers are an important approach to safeguarding local people's access to resources. It is noteworthy that neither of the sample concessions in this study harvested Moabi trees on their 2012 cutting areas, respecting an agreement with the local communities who harvest the fruits for their seed oil, but the densities of commercial sized trees on the concession were already much lower than they were around the neighboring villages (Noutcheu et al., 2016).

The potential conflicts between collecting food resources and logging are not limited, however, to timber-producing industrial logging concessions. In two of the sample villages, most of the collection trees were located within gazetted community forests, while in the other two villages they were are in unclassified forest estate, or what have been described as "domestic forests," where local people's uses reflect customary rights (Lescuyer, 2012). Community forests were formally given legal status 20 years ago in the revision of Cameroon's forest code and to date fewer than two million ha have been gazetted (Mertens et al., 2012). Although community forestry can theoretically provide a number of financial and development benefits, not to mention safeguarding the collection of forest food resources, in practice in Cameroon the majority of benefits are obtained only by individuals or specific groups, rather than the community as a whole (Ezzine de Blas et al., 2011; Ofoulhast-Othamot, 2014). Furthermore, guidelines for their use, under the control of the Ministry of Forests, limits some uses that would otherwise have been permitted under customary rights (Lescuyer, 2012). 


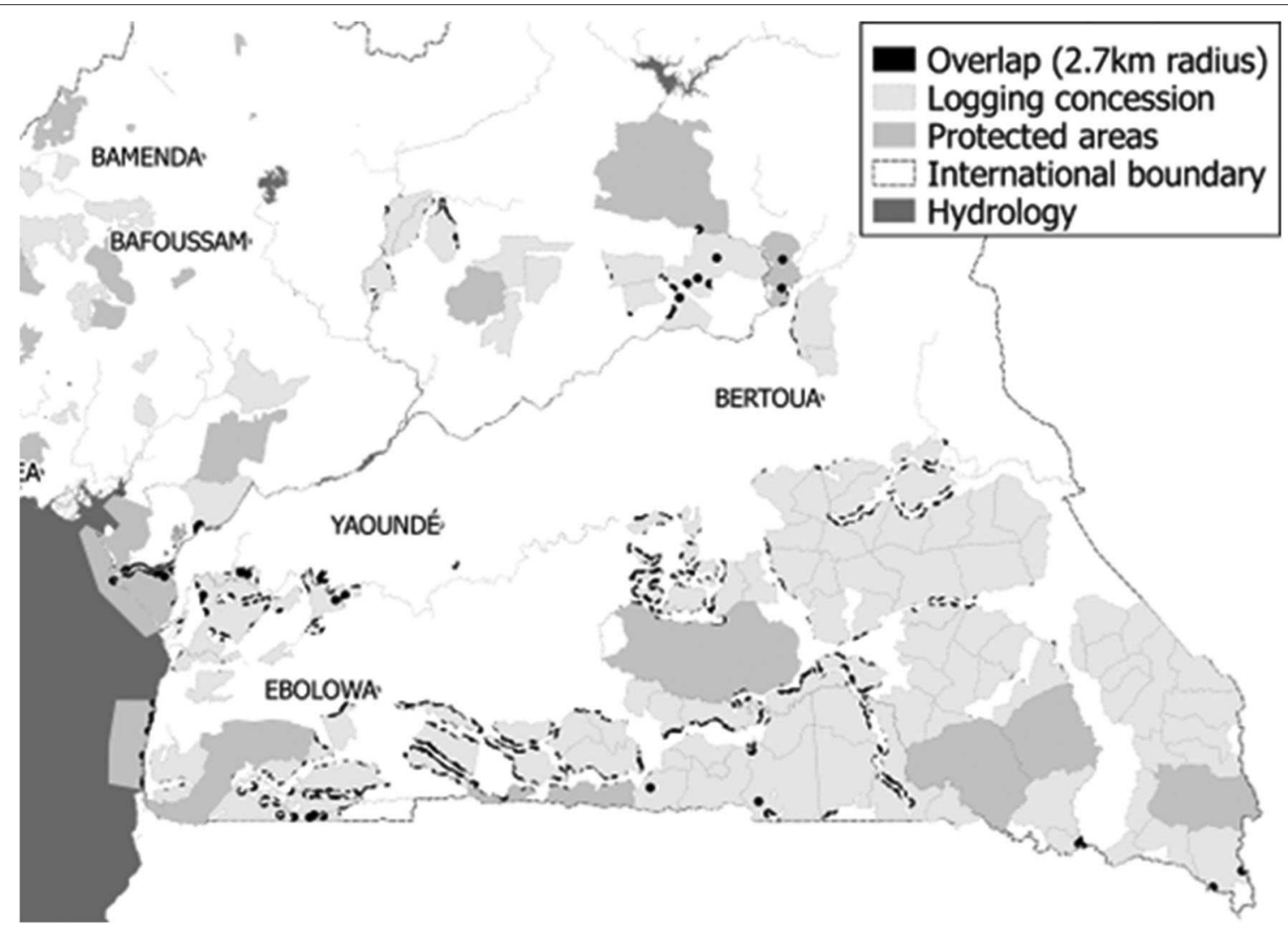

FIGURE 10 | Map of the average $2.7 \mathrm{~km}$ radius "resource shed" of each village in the humid dense forest zone of Cameroon overlaps with logging concessions and protected areas.

Although local communities have been granted rights to the use and sale of a range of forest resources in community forests, in Cameroon the main activity in these forests has been timber production (Logo, 2003). Because they produce low volumes, community forests sell to the domestic market. These buyers would purchase lower diameter trees than industrial concessionaires would be legally able to sell-or economically able to process-for the export market. This means that community forests are likely to remove a higher proportion of timber trees than would a concessionaire. Baka villagers involved in our study reported that felling of trees in the community forest meant they had to travel further to obtain non-timber products from those species.

Equally or even more challenging to the conservation of trees that yield foods is the burgeoning yet poorly regulated informal timber sector, which is estimated to be much larger than the export sector in terms of annual sawn wood production volume (Lescuyer et al., 2012). There is little information concerning species-specific volumes or felling diameters, but Moabi and Sapelli are among the timbers exploited by artisanal sawyers. In the Congo Basin there is a duality in forest tenure where access to forests and their resources blur traditional rights and formal tenure systems (Lescuyer, 2012; Sidle et al., 2012). The decision-making process in local communities includes formal and informal arrangements to decide whether a tree should be felled or conserved. The formal arrangement is between the community and the government and/or concessionaires, and it determines the resources to which the community will maintain access within a given area; while the informal arrangement is between the community and groups or individuals with interests in the resources to which the community has access (Lescuyer, 2012).

In the case of multiple-use tree species, the trade-off between a one-time cash injection based on the timber value of a tree and the long-term returns from multiple harvests of lower value products important for nutritional, medicinal, economic, or cultural purposes, has multiple dimensions. One of these relates to total sale price. Although very low, the $\$ 34-\$ 180$ sale price of a tree represent a significant quantity of money for people who have few sources of cash and may need large infusions on occasion, for example, to pay for medical emergencies. Nonetheless, the value of repeated harvests of nontimber products can be worth more than the one-time sale value of a tree for timber. Using a $10 \%$ discount rate, Schneemann (1995) calculated that over 7.5 years, the present value of Moabi oil derived from a single tree (\$2408) exceeded its timber value for the export market (at that time, USD $\$ 1850$ for a tree $100 \mathrm{~cm}$ in diameter). The value of sawn timber traded within the informal 
sector, for the domestic market, averages $80 \%$ less than the Cameroonian free on board (FOB) price for industrial timber (Cerruti and Lescuyer, 2011). Respondents indicated that selling a Moabi tree would bring $\$ 120$ USD equivalent, only 5\% of the value calculated by Schneemann (1995). This amount represents only $20 \%$ of the estimated annual value of its oil production, $\$ 638$ USD/year (Table 3). The average sale value of an individual Tali tree, as derived from the range of values given by respondents, represents only slightly more than the value of the caterpillars that it could yield each year (\$34 USD as compared to \$28 USD; Table 3). The large range of values given by informants may reveal that few actually know what these trees would sell for, but typically, trees purchased "on the stump" are paid for at very low rates, reflecting the discretion of the buyer, who needs to pay for the felling and the transport, as well as the processing, before being able to sell its wood products.

However, it is not simply the quantity of money resulting from selling forest products that must be taken into account, but also who receives that benefit. For example, it is typically women who most value Moabi fruits and oil and other food products (Ngueguim et al., 2011), primarily as food for consumption, but also for sale. Like women, Baka value food products more than the monetary value of timber (Lewis, 2001). Selling timber has been found to provide the most significant forest income source, but benefits a very few individuals (Makoudjou et al., 2017). For trees that yield both timber and non-timber food products, logging that benefits one or a few represents a loss of access to other resources over many years, for a large number of people. Even within communities, negotiation is needed to safeguard the interests in food resources of some members of the community that are in conflict with the interests of others in felling trees.

This study was limited in its scope and in its season. The mapping was not carried out during the season when caterpillars or Moabi fruits were being collected. Moabi trees have been reported to "belong" to individuals (Schneemann, 1995), meaning that collectors would be very aware of which ones were theirs, even outside of the fruiting season. This has not been reported for trees that yield caterpillars. Carrying out a participatory mapping study during the collection season might yield additional insights beyond those obtained in this study. If participatory mapping were to be used to develop management plans for multiple use tree species within a concession (or any other area), it would be important to involve a larger group of collectors than we were able to do, as was apparently done in the Congo by CIP (Hopkin, 2007).

In conclusion, according to the 1994 revisions to the forest law in Cameroon, communities are permitted to collect NTFPs within logging concessions for consumption, but not for sale. However, these laws do not specifically make reference to multiple-use tree species and do not provide guidelines for how to ensure that local people have equitable access rights to these resources. Such guidelines are needed, and must be developed to respond to the specific needs and uses of the local populations, both men and women. The majority of the source trees for the foods studied were found to be of an appropriate size for felling, meaning the trees within logging concessions could still be legally felled by the concession operator. Some logging concessions, including the SCTB concession in this study, have recently agreed not to fell Moabi to avoid conflicts with local communities who value their fruits and seed-oil (Asseng Ze, 2008); however unlike Gabon, where the felling of Moabi has been prohibited due to its value to local communities (IUCN-CARPE, 2009), this is not a policy in Cameroon. Despite the apparent local importance of caterpillars to the diets of rural forest-dwelling people, there are no regulations that take into account the importance of timber species such as Sapelli or Tali as food sources for these caterpillars.

In light of the fact that most forests in the Congo Basin are inhabited, multiple resource management for multiple beneficiaries, including inclusive governance for the management of overlapping rights, particularly related to use of non-timber resources, should be implemented within industrial concessions, as called for by Forests Monitor (2001) and Karsenty and Vermeulen (2016). This may require participatory mapping of resource trees, with particular attention paid to tree species that yield both timber and NTFPs. Since most rural villagers collect on foot, and the distances they travel during day trips to obtain these resources are limited (in the case of this study, $2.7 \mathrm{~km}$ on average, up to $6 \mathrm{~km}$ ) the total area for which such combined management would be required could be a small proportion of the areas allocated to timber concessions (Figure 10). Nonetheless, the 335,000 ha of timber concession lands that were calculated to occur within $2.7 \mathrm{~km}$ of villages represent a significant, and minimum, area where multiple resource management is called for, at least for these food resources.

This study found that $86 \%$ of the trees from which villagers collected food resources were located outside the timber concessions, within community forests or on so-called "domestic forests," outside the permanent forest estate (Lescuyer, 2012). Harvesting timber from community forests, or for the informal timber market, from so-called "domestic forests," may represent more of a threat to NTFP resources than industrial timber concessions. This is because industries that are granted timber concessions are legally required to consider local needs, whereas community forests and informal logging typically benefit a few individuals, and logging may be carried out in the absence of legally defined mechanisms to safeguard other interests in those trees. The fact that the value of timber sold to the domestic market is so much lower than the value of timber sold to the export market may represent a safeguard, in that the value of the NTFP harvest in one year may exceed the value of the tree for timber. Nonetheless, the individual or the small group that would benefit from selling the tree for timber might have more power than those who would benefit from the NTFP harvest, leading to a decision to fell a tree that would yield more benefits if left standing.

Participatory mapping of resources has been done in countries around the world, typically with the objective of defining the areas to which local people have rights, but also to map trees of value within timber concessions. This study used participatory mapping to determine where local people obtained wild food resources, revealing that among these four villages, most collection trees were NOT on concession lands. It also recognizes that industrial timber harvesting for export, with high minimum 
cutting diameters and legal requirements calling for agreements with local villagers, need not undermine access to food resources from timber trees, even where these are on timber concessions. However, mapping and management guidelines for multiple use species are needed. Such multiple-resource management would enhance the benefits and the beneficiaries from tropical forest management in Africa, which is currently focused almost exclusively on the extraction of timber products for export. This study also revealed that community forestry, as practiced in Cameroon, and informal logging, carried out by local villagers within their "domestic forests," could represent an even greater threat to the survival of food-source trees. To address the conflicts of interest between rural people who seek revenue from a onetime timber sale as opposed to those who want to retain access to food resources that can be harvested over and over again, from the same tree, processes and mechanisms for negotiation among users with different interests should be promoted and supported, not only within industrial timber concessions, but also on community forests and within domestic forests.

\section{DATA AVAILABILITY STATEMENT}

The datasets generated for this study are available on request to the corresponding author.

\section{ETHICS STATEMENT}

The studies involving human participants were reviewed and approved by Bioversity International, CIFOR and local partner organisations in Cameroon (IRAD), Gabon (IRET) and the DRC (UNIKIS). All research activities were done in accordance with the local legislation and institutional requirements. Informed consent to participate in this study was provided by the participants.

\section{REFERENCES}

Amon, A. A., Ahipo, D. E., Kouadio, E. N., and Kouamé, L. P. (2009). Nutritional value and physico-chemical characterization of the fat of the caterpillar (Imbrasia oyemensis) dried and sold at the Adjamé market in Abidjan, Côte d'Ivoire. J. Anim. Plant Sci. 3, 243-250.

Asseng Ze, A. (2008). Gestion Durable des Produits Forestiers Non-ligneux Dans la Concession Forestiere de Pallisco. Rome: FAO. Available online at: http://www. fao.org/3/k3611f/k3611f00.htm (accessed June 09, 2020).

ATIBT, (2007). Etude sur le plan pratique d'Amenagement des Forests Naturelles de Production Tropicales Africaines. Paris: Association Technique Internationale des Bois Tropicaux (ATIBT). 136.

Balinga, M., Monzambe Mapunzu, P., Moussa, J.-P., and N'gasse, G. (eds.). (2004). Contribution des insectes de la forêt a la Sécurité Alimentaire : L'exemple des Chenilles d'Afrique Centrale. Produits forestiers non ligneux. Document de Travail No. 1. Rome: Département des Forets, FAO, 106.

Bayol, N., Demarquez, B., de Wasseige, C., Eba’a Atyi, R., Fisher, J-F., Nasi, R., et al. (2012). "Forest management and the timber sector in Central Africa," in The Forests of the Congo Basin - State of the Forest 2010, eds C. de Wasseige, P. de Marcken, N. Bayol, F. Hiol Hiol, P. Mayaux, B. Desclee, et al. (Luxembourg: Publications Office of the European Union), 43-61.

BUCREP. (2012). Bureau Central des Recensements et des Etudes de Population $3 e$ RGPH: La Population du Cameroun en 2010. Institut National de la Statistique

\section{AUTHOR CONTRIBUTIONS}

PM collected the field data, analyzed the results, developed the figures and tables, and drafted and revised the paper. PD collected field data from female collectors. LS wrote the grant proposal and obtained the funding from the Congo Basin Forest Fund, supervised the Beyond Timber project, including this research, and carried out multiple revisions of the paper.

\section{FUNDING}

This study was part of the project "Beyond Timber: Reconciling the needs of the logging industry with those of forestdependent communities" (2011-2014), led by Bioversity International and funded by the Congo Basin Forest Fund, the CGIAR Research Programme on Forests, Trees and Agroforestry, and the Government of Italy. The first author's time was financed by Finland's Ministry for Foreign Affairs and Centre for International Mobility Junior Professional Officer programme.

\section{ACKNOWLEDGMENTS}

Dr. Julius Chupezi Tieguhong facilitated the work as the "Beyond Timber" Project Coordinator, alongside Dr. Mathurin Tchatat of the Institut de Recherche Agricole pour le Developpement (IRAD), the project focal point for Cameroon. Informants in Meyos, Ndembo, Ngone, and Nkolbikon villages in Cameroon were invaluable during the study, guiding the researchers over an estimated $300 \mathrm{~km}$ of forest paths to find trees, and providing information about their uses. We thank the concessionaires, and personnel of FIPCAM, and SCTB, for their support. Two reviewers made valuable contributions.

du Cameroun, Yaounde, Cameroon. Available online at: from http://www. statistics-cameroon.org/news.php?id=18 (Accessed December, 2015).

Cerruti, P. O., and Lescuyer, G. (2011). The Domestic Market for SmallScale Chainsaw Milling in Cameroon. Present Situation, Opportunities and Challenges. Occasional Paper 61. Bogor: Center for International Forestry Research. 38.

Cerutti, P. O., Mbongo, M., and Vandenhaute, M. (2016). State of the Timber Sector in Cameroon (2015) - FAO/CIFOR Report. Bogor: FAO/ CIFOR. 31.

Cerutti, P. O., Nasi, R., and Tacconi, L. (2008). Sustainable forest management in Cameroon needs more than approved forest management plans. Ecol. Soc. 13:36. doi: 10.5751/ES-02591-1 30236

Clark, L. E., and Sunderland, T. C. (2004). The Key Non-Timber Forest Products of Central Africa: State of the Knowledge. Washington: USAID.

Colfer, C., Basnett, B., and Elias, M. (2016). Gender and Forests. Climate Change, Tenure, Value Chains and Emerging Issues. Earthscan from Routledge. 331. doi: 10.4324/978131566624

Debroux, L. (1998). L'aménagement des forêts tropicales fondé sur la gestion des populations d'arbres: l'exemple $d u$ Moabi (Baillonella toxisperma, Pierre) dans le forêt du Dja, Cameroun. Thèse de doctorat. Belgique: Faculté Universitaire des Sciences Agronomiques de Gembloux. 283. 
EnviroConsulting. (2009). Étude dimpact environnemental des activités d'exploitation de la concession forestière $n^{\circ} 1050$ (UFA 09017 and 09018) située dans les arrondissements d'Ebolowa II, Biwong bulu et de Mvangan département de Lamvila, région du sud. Yaounde: Fabrique Camerounaise de Parquet (FIPCAM).

Ezzine de Blas, D., Ruiz-Pérez, M., and Vermeulen, C. (2011). Management conflicts in Cameroonian community forests. Ecol. Soc. 16:8. doi: 10.5751/ES-03845-160108

Forests Monitor (2001). Sold Down the River. The Need to Control Transnational Forestry Corporations: a European Case Study. Cambridge: Forests Monitor. 73. FAO. (2016). Global Forest Resources Assessment, 2nd Edn. Rome: FAO. 243.

Fungo, R., Muyonga, J., Kaaya, A., Okia, C., Tieguhong, J. C., and Baidu-Forson, J. J. (2015). Nutrient quality and bioactive compounds of Baillonella toxisperma, Trichoschypa abut and Pentaclethra macrophylla from Cameroon. Food Sci Nutr. 3, 292-301. doi: 10.1002/fsn3.217

Fungo, R., Tieguhong, J. C., Iponga, D. M., Tchatat, M., Kahindo, J. M., Muyongaa, J. H., et al. (2020). The contribution of forest foods from logging concessions to food security and dietary intake of rural populations: insights from Gabon, DR Congo and Cameroon. International Forestry Review.

Fungo, R. J., Muyonga, M., Kabahenda, A., Kaaya, C., Okia, J., Loo, L. et al. (2016). Contribution of forest foods to women's nutrient intake and their association with household food insecurity: a cross-sectional study among women in Cameroon. Public Health Nutr. 19, 3185-3196. doi: $10.1017 / S 1368980016001324$

Guariguata, M., Garcia-Fernandez, C., Sheil, D., Nasi, R., Herrero-Jauregui, C., Cronkleton, P., et al. (2010). Compatibility of timber and non-timber forest product management in natural tropical forests: perspectives, challenges, and opportunities. Forest Ecol Manag. 259, 237-245. doi: 10.1016/j.foreco.2009.11.013

Hawthorne, W. (1998). Entandrophragma cylindricum. IUCN Red List of Threatened Species (Version 2013.1). Availeble online at: www.iucnredlist.org (Accessed September 13, 2013).

Hoare, A. L. (2007). The Use of Non-Timber Forest Products in the Congo Basin: Constraints and Opportunities. London: The Rainforest Foundation.

Hopkin, M. (2007). Mark of respect. Nature 448, 402-403. doi: 10.1038/448402a

Ingram, V., and Schure, J. (2010). Review of Non Timber Forest Products (NTFPs) in Central Africa. Yaounde: CIFOR.

Ingram, V., Schure, J., Tieguhong, J., Ndoye, O., Awono, A., and Iponga, D. (2014). Gender implications of forest product value chains in the Congo Basin. Forests Trees Livelihoods 23, 67-86. doi: 10.1080/14728028.2014.887610

IUCN-CARPE. (2009). Recueil des textes juridiques en matière de conservation et d'utilisation des ressources naturelles au Gabon. Washington: USAID.

Karsenty, A., and Vermeulen, C. (2016). Toward "Concessions 2.0": articulating inclusive and exclusive management in production forests in Central Africa. Int. Forestry Rev. 18(Suppl.1), 1-13. doi: 10.1505/146554817822295939

Laird, S. (1995). The Natural Management of Tropical Forests for Timber and Non-timber Products. Oxford: Oxford Forestry Institute.

Laird, S. (1999). "The management of forests for timber and non-timber forest products in central Africa," in Non-Wood Forest Products of Central Africa: Current Research Issues and Prospects for Conservation and Development, eds T. C. H. Sunderland, L. E. Clark, and P. Vantomme (Rome: FAO), 51-60.

Lescuyer, G. (2012). Sustainable forest management at the local scale: a comparative analysis of community forests and domestic forests in cameroon. Small-scale Forestry. 12, 51-66. doi: 10.1007/s11842-012-9199-x

Lescuyer, G., Cerutti, P., Mendoula, E., Eba’a Atyi, R., and Nasi, R. (2012). "An appraisal of chainsaw milling in the Congo Basin," in The Forests of the Congo Basin - State of the Forest 2010, eds C. de Wasseige, P. de Marcken, N. Bayol, F. Hiol Hiol, P. Mayaux, B. Desclee, et al. (Luxembourg: Publications Office of the European Union), 97-107.

Levang, P., Lescuyer, G., Noumbissi, D., Déhu, C., and Broussolle, L. (2015). Does gathering really pay? Case studies from forest areas of the East and South regions of Cameroon. Forests Trees Livelihoods. 24, 128-143. doi: $10.1080 / 14728028.2014 .1000980$

Lewis, J. (2001). "Indigenous uses for the sapelli tree in northern Congo," in Sold Down the River. The Need to Control Transnational Forestry Corporations: a European Case Study (Cambridge: Forests Monitor), 7.

Logo, P. B. (2003). The decentralized forestry taxation system in Cameroon: local management and state logic. Washington: World Resources Institute.
Louppe, D. (2005). "Baillonella toxisperma Pierre," in PROTA (Plant Resources of Tropical Africa/Ressources végétales de l’Afrique tropicale), eds D. Louppe, A. A. Oteng-Amoako, and M. Brink (Wageningen).

Makoudjou, A., Levang, P., and Tieguhong, J.C. (2017) The role of forest resources in income inequality in Cameroon. Forests Trees Livelihoods 26, 271-285. doi: $10.1080 / 14728028.2017 .1297258$

Mapaga, D., Ingueza, D., and Louppe, D. (2002). Moabi. Projet FORAFRI et IRAF, Libreville. Montpellier: CIRAD-Foret.

Medinof (2004). Plan d'aménagement des concessions no. 1046/UFA10046 et No 1059/UFA 1009 et 10060. Yaounde: Societe Camerounaise de Transformation du Bois (SCTB); Gouvernement de Cameroun. 72.

Mertens, B., Neba Shu, G., Steil, M., Tessa, B., Minnemeyer, C., Douard, P., et al. (2012). Interactive Forest Atlas of Cameroon (Version 3.0). Washington DC: World Resources Institute.

MINFOF. (2005). Societe Camerounaise de Transformation du Bois (SCTB). Plan d'Amanagement de la Concession 1046 (UFA 10 046, UFA 10 059, UFA 10 060), Agrement $n^{\circ}$ 0209/CAB/MINFOF. Yaounde: Ministère des Forets et de la Faune (MINFOF).

Muvatsi, P., Kahindo, J.-M., and Snook, L. (2018). Can the production of wild forest foods be sustained in timber concessions? The impact of logging on the availability of edible caterpillars hosted by sapelli (Entandrophragma cylindricum) and tali (Erythrophleum suaveolens) trees in the Democratic Republic of Congo. Forest Ecol. Manag. 410, 56-65. doi: 10.1016/j.foreco.2017.12.028

Muvatsi, P., Kahindo, J.-M., and Snook, L. (in press). The yield of edible caterpillars from valuable timber trees sapelli (Entandrophragma cylindricum) and tali (Erythrophleum suaveolens) in the Democratic Republic of the Congo.

Ndoye, O., Manuel, R., and Eyebe, A. (1997). The markets of non-timber forest products in the humid forest zone of Cameroon. Rural Development Forestry Network. London: Overseas Development Institute.

Ndoye, O., and Tieguhong, J. (2004). Forest resources and rural livelihoods: the conflict between timber and non-timber forest products in the Congo Basin. Scand. J. Forest Res. 19, 1-9. doi: 10.1080/14004080410034047

Newing, H. (2007). "Chapter 4.1: Social impacts of industrial logging concessions: effects on forest user rights," in Concessions to Poverty. The Environmental, Social and Economic Impacts of Industrial Logging Concessions in Africa's Rainforests, eds S. Simon Counsell, C. Long, and S. Wilson (London: The Rainforest Foundation, UK; Forest Monitor), 57-68.

N'Gasse, G. (2004). "Ch. 2.2: Contribution des chenilles/larves comestibles à la réduction de l'insécurité alimentaire en République Centrafricaine," in Contribution des insectes de la forêt a la Sécurité Alimentaire : L'exemple des Chenilles d'Afrique Centrale. Produits forestiers non ligneux, Document de Travail No. 1, eds M. Balinga, P. Monzambe Mapunzu, J.-P. Moussa, and G. N'gasse (Rome: Département des Forets, FAO), 50-64.

Ngueguim, J. R., Dondjang, J. P., Onana, J., Ijang, P. T., Zapfack, L., Noumi, V. N., et al. (2011). Moabi (Baillonella toxisperma Pierre): arbre à usage multiple de forêt dense humide du Cameroun. Int. J. Biol. Chem. Sci. 5, 2395-2406. doi: 10.4314/ijbcs.v5i6.19

Noumbissi, D. (2012). Usages locaux des ressources forestieres autour de troisConcessions Camerounaise (1050, 1046 et 1059): Complémentarité ou Competition? Mémoire d'Ingenieur. Cameroun: Université de Dschang. p. 92.

Noutcheu, R., Snook, L., Tchatat, M., Taedoumg, H., Tchingsabe, O., and Tieguhong, J. (2016). Do logging concessions decrease the availability to villagers of foods from timber trees? A quantitative analysis for Moabi (Baillonella toxisperma), Sapelli (Entandrophragma cylindricum) and Tali (Erythrophleum suaveolens) in Cameroon. Forest Ecol. Manag. 381, 279-288. doi: 10.1016/j.foreco.2016.09.039

Ofoulhast-Othamot, G. (2014) Decentralization of natural resources management and improvement of rural livelihoods: empirical evidence from the Dimako Council Forest experiment in eastern Cameroon. Forests Trees Livelihoods 23, 175-187. doi: 10.1080/14728028.2014.912951

Republic of Cameroon (1994). LOI N 94/01 du 20 janvier 1994 portant régime des forêts, de la faune et de la pêche. Available online at: https://wipolex.wipo.int/ en/legislation/details/7463 (accessed March, 2020).

Rist, L., Shanley, P., Sunderland, T., Sheil, D., Liswanti, N., Ndoye, O., et al. (2012). The impacts of logging on non-timber forest products of livelihood importance. Forest Ecol. Manag. 268, 57-69. doi: 10.1016/j.foreco.2011. 04.037 
Schneemann, J. (1995). Exploitation of Moabi in the humid dense forests of Cameroon: harmonization and improvement of two conflicting ways of exploitation of the same forest resource. BOS Nieuwsletter 14, 20-32.

Shanley, P., da Serra Silva, M., Melo, T., Carmenta, R. Nasi, R., (2012). Conflict of use to multiple use: forest management innovations by small holders in Amazonian logging frontiers. Forest Ecol. Manag. 268, 70-80. doi: 10.1016/j.foreco.2011.05.041

Sidle, J. G, Dupain, J., Beck, J., Nackoney, J., de Wasseige, C., Mendomo Biang, J. D., et al. (2012). "Forest zoning experience in Central Africa," in The Forests of the Congo Basin - State of the Forest 2010, eds C. de Wasseige, P. de Marcken, N. Bayol, F. Hiol Hiol, P. Mayaux, B. Desclee, et al. (Luxembourg: Publications Office of the European Union), 43-61.

Sunderland, T. C. H., Cunningham, A. B., Tchoundjeu, Z., Ngo-Mpeck, M. L., and Laird, S. A. (2004). "Chapter 6: Yohimbe. (Pausinystalia johimbe)," in The Key Non-Timber Forest Products of Central Africa: State of the Knowledge, eds L. Clark and T. Sunderland (Washington, DC: USAID Bureau for Africa), 121-140.

Sunderlin, W., and Pokam, J. (2002). Economic crisis and forest cover change in Cameroon: the roles of migration, crop diversification, and gender division of labor. Econ. Dev. Cultur. Change 50, 581-606. doi: 10.1086/3 42358

Termote, C., Bwamameyi, M., Dhed'a djailo, C., Huybregts, L., Lachat, C., Kolsteren, P., et al. (2012). A biodiverse rich environment does not contribute to a better diet: a case study from DR Congo. PLoS ONE 7:e30533. doi: 10.1371/journal.pone.0030533

The World Bank. (2016). Rural population (\% of total population) - Cameroon. Available online at: https://data.worldbank.org/indicator/SP.RUR.TOTL.ZS? locations=CM (accessed July 25, 2016).

Tieguhong, J., and Ndoye, O. (2007). Forest Harvesting Case Study 23: The Impact of Timber Harvesting in Forest Concessions on the Availability of Non-wood Forest Products (Nwfp) in the Congo Basin. Rome: FAO. 50
Tieguhong, J., and Nkamgnia, E. (2012). Household dependence on forests around Lobeke National Park, Cameroon. Int. Forestry Rev. 14, 196-212. doi: 10.1505/146554812800923426

Tieguhong, J. C., Ndoye, O., Grouwels, S., Mala, W. A., and Betti, J. L. (2012). Rural enterprise development for poverty alleviation based on nonwood forest products in Central Africa. Int. Forestry Rev. 14, 363-379. doi: $10.1505 / 146554812802646701$

Van Djik, J. F. W. (1999). Non-timber Forest Products in the Bipindi-Akom II Region, Cameroon: A Socioeconomic and Ecological Assessment. TropenbosCameroon.

Vantomme, P., Gohler, D., and N'Deckere-Ziangba, F. (2004). Contribution of Forest Insects to Food Security and Forest Conservation: The Example of Caterpillars in Central Africa. London: Overseas Development Institute Wildlife Briefing. 4.

White, L. (1998). "Baillonella toxisperma," in IUCN 2013. IUCN Red List of Threatened Species. Version 2013.1. Available online at: www.iucnredlist.org (accessed September 13, 2013).

WRI, Gfw, Minfof (2005). Atlas Forestier Interactif du Cameroun: Version 1.0 World Resources Institute. Washington, DC. 48.

Conflict of Interest: The authors declare that the research was conducted in the absence of any commercial or financial relationships that could be construed as a potential conflict of interest.

Copyright (c) 2020 Maukonen, Donn and Snook. This is an open-access article distributed under the terms of the Creative Commons Attribution License (CC BY). The use, distribution or reproduction in other forums is permitted, provided the original author(s) and the copyright owner(s) are credited and that the original publication in this journal is cited, in accordance with accepted academic practice. No use, distribution or reproduction is permitted which does not comply with these terms. 


\section{APPENDIX 1: QUESTIONNAIRE}

Questions about the tree

- When do you collect the moabi/caterpillars from this tree?

- Does this tree produce these every year?

- How many times do you collect from this tree in a season?

- Has the amount that you collect or the amount available from this tree increased, decreased or stayed the same over the last 5 years?

- Are there trees of this species that do not produce these products, how many and why?

- Has the number of this particular tree species increased, decreased or remained the same over time?

- Who is entitled to collect products from this tree (for consumption, sale and timber) - Women, men, children, everyone or selected individuals?

- If access is limited, who controls the access and how?

- Do you organize specific collection trips for the resource from this tree?
Questions about the resource (these can be asked throughout the day)

- Has the collection distance increased, decreased or stayed the same in the last 5 years?

- Has the availability of the product increased, decreased or remained the same in the last 5 years?

- Do you sell the resource, and what is the proportion consumed and the proportion sold?

- For how long have you been selling them?

- How is the market for the product and how has it changed in the last 5 years?

- To whom do you sell it and where?

- How much do people pay for it (per unit to be defined)?

- Do you transform the product?

- Who does that work (men, women and/or children)?

- Do you use the transformed product at home?

- Do you sell the transformed product? To whom and for how much?

- How much can you get from the sale of such a tree? 